\title{
Investigation of the cardioprotective effect of selective NCX inhibition in cellular models
}

\author{
PhD Thesis
}

Anita Kormos, MSc

Department of Pharmacology and Pharmacotherapy

University of Szeged

Szeged

Hungary 


\title{
STUDIES RELATED TO THE THESIS
}

I. Kormos A, Nagy N, Acsai K, Vaczi K, Agoston S, Pollesello P, Levijoki J, Szentandrassy $N$, Papp JGy, Varro A, Toth A

Efficacy of selective NCX inhibition by ORM-10103 during simulated ischemia/reperfusion.

EUROPEAN JOURNAL OF PHARMACOLOGY 740: pp. 539-551(2014)

IF.: 2,754

II. Nagy N, Kormos A, Kohajda Z, Szebeni A, Szepesi J, Pollesello P, Levijoki J, Acsai K, Virag L, Nanasi PP, Papp JGy, Varro A, Toth A

Selective $\mathrm{Na}^{+} / \mathrm{Ca}^{2+}$ exchanger inhibition prevents $\mathrm{Ca}^{2+}$ overload induced triggered arrhythmias.

BRITISH JOURNAL OF PHARMACOLOGY 171:pp.5665-5681(2014)

IF.: 4,99

\section{OTHER STUDIES}

I. Nagy N, Acsai K, Kormos A, Sebök Zs, Farkas AS, Jost N, Nánási PP, Papp JGy, Varró A, Tóth $A$

$\left[\mathrm{Ca}^{2+}\right]_{i}$-induced augmentation of the inward rectifier potassium current $\left(\mathrm{I}_{K 1}\right)$ in canine and human ventricular myocardium.

PFLÜGERS ARCHIV - EUROPEAN JOURNAL OF PHYSIOLOGY 465:(11) pp. 1621-

1635 (2013)

IF.: 3,073

\begin{abstract}
S
I. Prorok J., Nagy N., Kormos A., Acsai K., Papp J.Gy., Varró A., Tóth A.

A $\mathrm{Na}^{+} / \mathrm{Ca}^{2+}$ cseremechanizmust blokkoló SEA0400 hatása intracelluláris szívizomsejtekben.

CARDIOLOGIA HUNGARICA 38:Suppl.B: p.B20 (2008)

II. Nagy N, Szentandrássy N, Szebeni Á, Kormos A, Acsai K, Nánási P, Papp JGy, Varró A, Tóth A

Inhibition of sodium-calcium exchanger reduces the sodium induced calcium overload in canine myocardium. (A nátrium-kálcium exchanger gátlás csökkenti a nátrium indukált calcium overloadot kutya szívizomban)

CARDIOLOGIA HUNGARICA 41:(Suppl. F) pp. F38-F39. (2011)
\end{abstract}


III. Kormos A, Nagy N, Szebeni A, Szentandrassy N, Acsai K, Papp JGy, Varró A, Tóth A Partial NCX inhibition - via limiting $\mathrm{Ca}^{2+}$ influx - exerts a protective role against $\mathrm{Na}^{+}$induced $\mathrm{Ca}^{2+}$ overload in canine ventricular myocardium. (Részleges NCX-gátlás - a $\mathrm{Ca}^{2+}$ -beáramlás csökkentésével - védö hatást fejt ki a $\mathrm{Na}^{+}$-indukált $\mathrm{Ca}^{2+}$-túltöltödés ellen kutya kamrai szivizomban.)

CARDIOLOGIA HUNGARICA 42:(Suppl.A) p. A18. (2012)

IV. Kormos A, Márton Z, Oravecz K, Jost N, Varró A, Papp JGy, Acsai K A szelektív $\mathrm{Na}^{+} / \mathrm{Ca}^{2+}$ exchanger (NCX) gátlás inotrop hatása a $\mathrm{Ca}^{2+}$-influx és -efflux mód $\mathrm{Ca}^{2+}$-egyensúlyban betöltött relatív szerepétöl függ kutya szivizomsejtekben. (Inotropic consequences of selective $\mathrm{Na}^{+} / \mathrm{Ca}^{2+}$ exchange inhibition depend on the relative contribution of $\mathrm{Ca}^{2+}$ influx and efflux mode to the $\mathrm{Ca}^{2+}$ balance of dog cardiac myocytes.) CARDIOLOGIA HUNGARICA 43:(Suppl.B) pp. B21-B22. (2013)

V. Oravecz K, Kormos A, Acsai K

A nátrium-kalcium exchanger új gátlószereinek vizsgálata a szivelégtelenség kezelésében kedvezö pozitiv inotróp és antiaritmiás hatások tekintetében In:

„Hiteles(ebb) tudományos prezentációk” címü VIII. Ph.D. - Konferencia elöadásai. Konferencia helye, ideje: Budapest, 2014.03.13. II. Kötet. pp. 23-25.(2014)

VI. Oravecz K, Kormos A, Acsai K

Investigation of the possible positive inotropic and antiarrhythmic efficacy of ORM 10103, a new selective inhibitor of the cardiac sodium-calcium exchanger

In: Szélpál Sz (szerk.)

I. Innovation in Science - Doctoral Student Conference Konferencia helye, ideje: Szeged, 2014.05.02-2014.05.03. eBook of Abstracts: p. 23. (2014) 


\section{ABBREVIATIONS AND ACRONYMS}

$\left[\mathrm{Ca}^{2+}\right]_{\mathrm{i}}$ : intracellular $\mathrm{Ca}^{2+}$

$\left[\mathrm{Ca}^{2+}\right]_{\mathrm{iD}}$ : diastolic $\mathrm{Ca}^{2+}$ level

AP: action potential

APD: action potential duration

ATP: adenosine-triphosphate

ATX-II: anemone toxin

cAMP: cyclic adenosine-monophosphate

CDI: $\mathrm{Ca}^{2+}$ dependent inactivation

CICR: $\mathrm{Ca}^{2+}$ induced $\mathrm{Ca}^{2+}$ release

$\mathrm{CN}^{-}$: cyanate

DAD: delay after depolarization

EAD: early after depolarization

ECC: excitation-contraction coupling

$\mathrm{I}_{\mathrm{CaL}}$ : L-type $\mathrm{Ca}^{2+}$ current

$\mathrm{I}_{\mathrm{Ca}}$ : inward $\mathrm{Ca}^{2+}$ current

$\mathrm{I}_{\mathrm{NaL}}$ : Late sodium current

LQTS $_{1,2,3}$ : long QT syndromes

NBC: $\mathrm{Na}+-\mathrm{HCO}^{-}$cotransporter

NCX: $\mathrm{Na}^{+}-\mathrm{Ca}^{2+}$ exchanger

NHE: $\mathrm{Na}^{+} / \mathrm{H}^{+}$exchanger

NKA : $\mathrm{Na}^{+} / \mathrm{K}^{+}$ATPase

ORM-10103 : NCX inhibitor

PKA: protein kinase A

PLB: phospholamban

PMCA : sarcolemmal $\mathrm{Ca}^{2+}$ ATPase

ROI : region of interest

ROS : reactive oxigen species

$\mathrm{RT}_{50}$ : half relaxation time

RyR: ryanodine receptor

SERCA: sarcoplasmic reticulum $\mathrm{Ca}^{2+}$ ATPase

SR: sarcoplasmic reticulum 


\section{TABLE OF CONTENTS}

SUMMARY

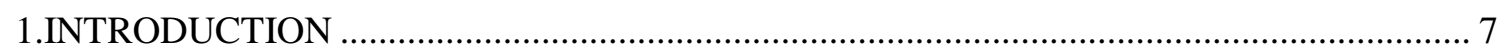

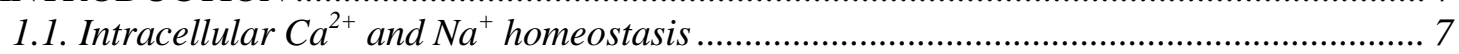

1.1.1. Intracellular $\mathrm{Ca}^{2+}$ handling in cardiac myocytes .................................................. 7

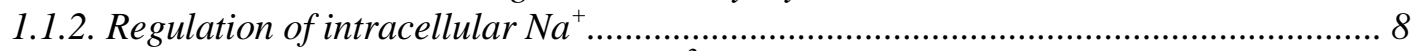

1.2. Regulation of the NCX by intracellular $\mathrm{Ca}^{2+}$ and $\mathrm{Na}^{+}$concentrations ............................. 9

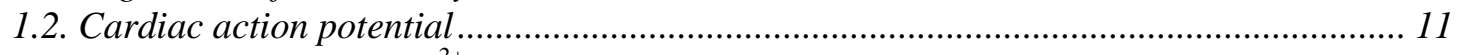

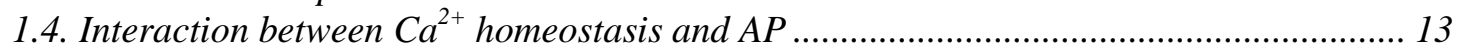

1.5. Effect of ischemia/reperfusion in cardiomyocytes........................................................... 14

1.6. The future perspectives of NCX modulation .................................................................. 15

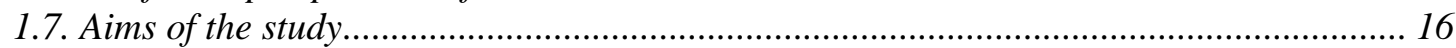

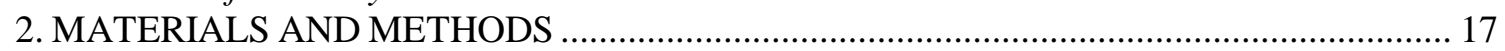

2.1. Isolation of canine left ventricular cardiomyocytes ……............................................... 17

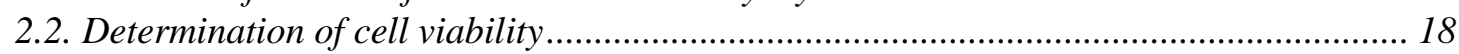

2.3. Validation of the simulated ischemia via NADH measurements .................................... 18

2.4. Measuring $\left[\mathrm{Ca}^{2+}\right]_{i}$ transients in single ventricular cardiomyocytes................................ 19

2.5. Monitoring of single cell action potentials ................................................................. 19

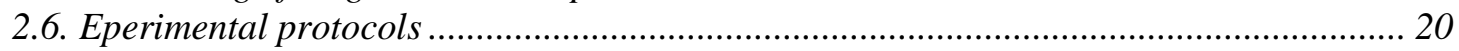

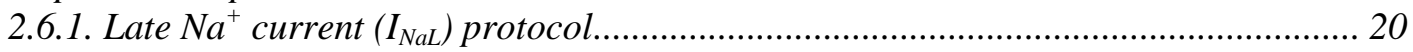

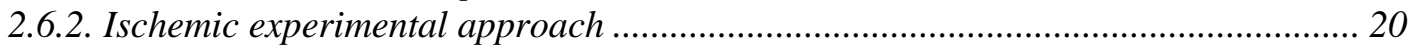

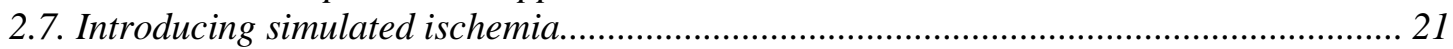

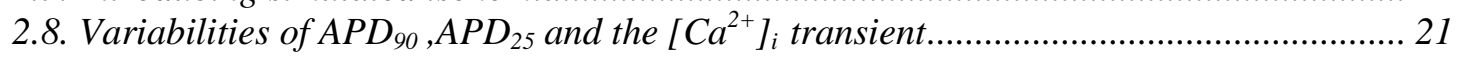

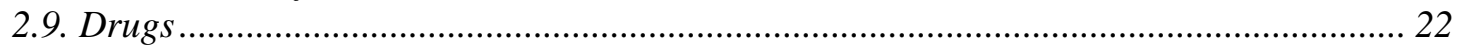

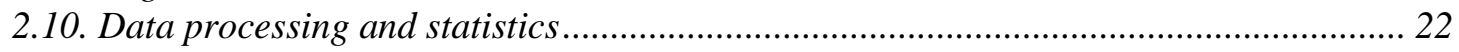

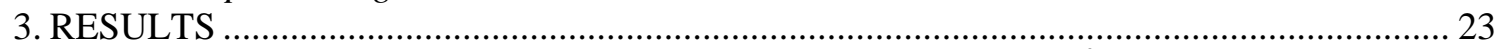

3.1. The physiological effect of selective NCX inhibition on the $\left[\mathrm{Ca}^{2+}\right]_{i}$ transient ................... 23

3.2. Effect of selective NCX inhibition on the $I_{N a L}$ induced increase in $\left[\mathrm{Ca}^{2+}\right]_{i}$ transient ........ 24

3.3. ORM-10103 decreased the spontaneous diastolic $\mathrm{Ca}^{2+}$ releases evoked by $\mathrm{Na}^{+} / \mathrm{K}^{+}$pump

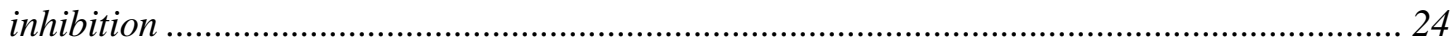

3.4. Effect of selective NCX inhibition on cardiomyocyte viability under ischemic conditions

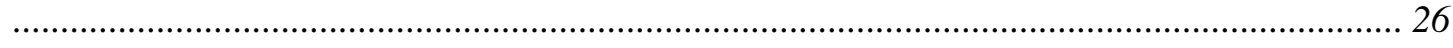

3.5. Validation of intracellular ischemia by monitoring NADH levels ................................. 28

3.6. The effect of selective NCX inhibition on the $\left[\mathrm{Ca}^{2+}\right]_{i}$ transient during simulated ischemia

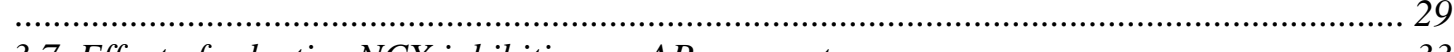

3.7. Effect of selective NCX inhibition on AP parameters.................................................. 33

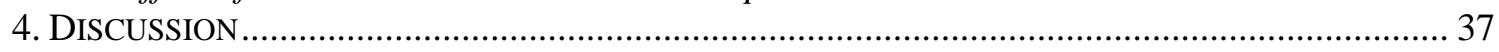

4.1. Selective NCX inhibition does not influence CaT kinetics under physiological conditions

4.2. The effect of selective NCX inhibition against $I_{N a L}$ induced $\left[\mathrm{Ca}^{2+}\right]_{i}$ rise on the $\left[\mathrm{Ca}^{2+}\right]_{i}$

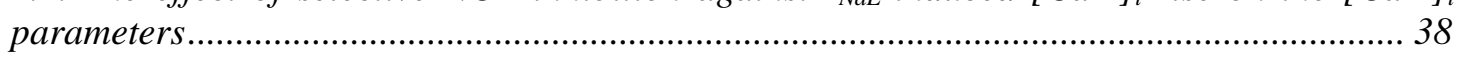

4.3. Selective NCX inhibition increased the cell survival during ischemia/reperfusion .......... 38

4.4. Measurement of the severity of intracellular ischemia..................................................... 39

4.5 The effect of selective NCX inhibition during simulated ischemia/reperfusion on the

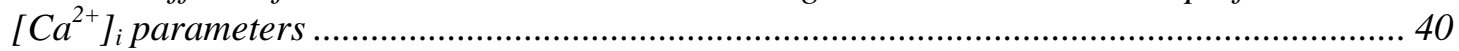

4.6. Selective NCX inhibition causes only minor changes on AP morphology ....................... 42

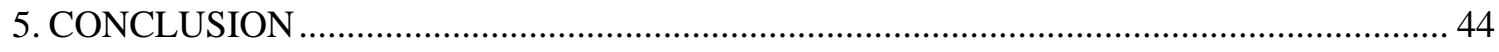

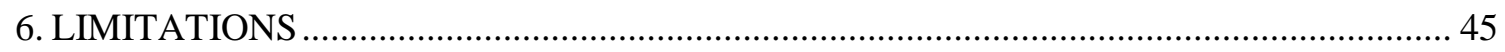

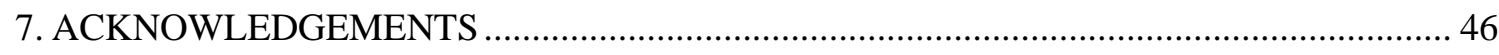

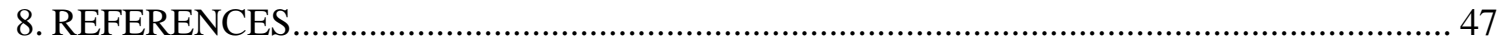

9. ANNEX 


\section{SUMMARY}

Cardiovascular diseases are the leading cause of mortality for both men and women worldwide. In many of the cardiac diseases $\left[\mathrm{Ca}^{2+}\right]_{\mathrm{i}}$ overload is a crucial factor in initiation and progression of the malignant intracellular perturbations leading to cell death. A substantial rise in cellular $\mathrm{Na}^{+}$content is often the primary initiator of the $\left[\mathrm{Ca}^{2+}\right]_{\mathrm{i}}$ overload, leading to arrhythmogenesis. This pathomechanism is also characteristic of ischemia (and especially reperfusion) or arrhythmia types with genetic origin (e.g. LQT3 syndrome). Indeed, $\left[\mathrm{Ca}^{2+}\right]_{\mathrm{i}}$ overload induced arrhythmias are among the most common cardiac diseases.

By its regulatory effect on the cytoplasmic $\mathrm{Ca}^{2+}$ the $\mathrm{Na}^{+} / \mathrm{Ca}^{2+}$ exchanger (NCX) has a crucial role in the ionic homeostasis of the heart. In physiological conditions its major role is to remove the excess $\mathrm{Ca}^{2+}$, and to stabilize the cellular $\mathrm{Ca}^{2+}$ content and the magnitude and kinetics of the $\left[\mathrm{Ca}^{2+}\right]_{\mathrm{i}}$ transient. Excessive increase in the inward $\mathrm{Na}^{+}$current may lead to arrhythmogenesis either via $\left[\mathrm{Na}^{+}\right]_{\mathrm{i}}$ induced $\left[\mathrm{Ca}^{2+}\right]_{\mathrm{i}}$ overload or by significantly prolonging the duration of the action potential (APD).

The primary aim of the present project was to investigate in detail the effects of $\left[\mathrm{Ca}^{2+}\right]_{\mathrm{i}}$ overload, induced either by increased late $\mathrm{Na}^{+}$current or by acute ischemia/reperfusion, on characteristic variables of the $\left[\mathrm{Ca}^{2+}\right]_{\mathrm{i}}$ transient $(\mathrm{CaT})$ and action potential $(\mathrm{AP})$, in isolated canine cardiomyocytes.

In order to meet our goals we first developed a simulated ischemia/reperfusion model to be used at the cellular level. (There was minimal related information in the literature.) Next, we applied this model to canine cardiomyocytes and investigated the variables of the APs and CaTs recorded from the cells in several experimental states. When applying the protocol "per se", ischemia/reperfusion induced changes were relatively moderate, therefore this protocol seems to be appropriate to evaluate the effects of moderate ischemia. In order to model more severe ischemia, the sarcolemmal $\mathrm{Na}^{+} / \mathrm{K}^{+}$ATPase was blocked simultaneously. Compared to the low-flow protocol, the observed changes in $\left[\mathrm{Na}^{+}\right]_{\mathrm{i}}$ and $\left[\mathrm{Ca}^{2+}\right]_{\mathrm{i}}$ homeostasis in strophantidine treated cells were much more dramatic during both ischemia and reperfusion.

On the whole, tha major results demonstrate that selective NCX inhibition exhibits considerable protection against the arrhythmogenic effect and cell death due to $\left[\mathrm{Ca}^{2+}\right]_{\mathrm{i}}$ overload when induced by increased late sodium current and ischemia/reperfusion. 


\section{INTRODUCTION}

\subsection{Intracellular $\mathrm{Ca}^{2+}$ and $\mathrm{Na}^{+}$homeostasis}

\subsubsection{Intracellular $\mathrm{Ca}^{2+}$ handling in cardiac myocytes}

Intracellular $\mathrm{Ca}^{2+}$ cycling (see Fig.1.) in the cardiomyocytes is a result of the tightly regulated Ca-influx and efflux pathways. The membrane depolarization initiates the sarcolemmal $\mathrm{Ca}^{2+}$ influx through the L-type $\mathrm{Ca}^{2+}$ channels, which are located in the membrane of T-tubules near the junctional region of the sarcoplasmic reticulum (SR) [12]. This "trigger calcium" is thought to directly activate the calcium release channels embedded in the junctional SR. Opening of these calcium-sensitive $\mathrm{Ca}^{2+}$ release channels (ryanodine receptors, RyR) partially empties the internal store of calcium. This mechanism is known as calcium-induced $\mathrm{Ca}^{2+}$ release (CICR) [3].

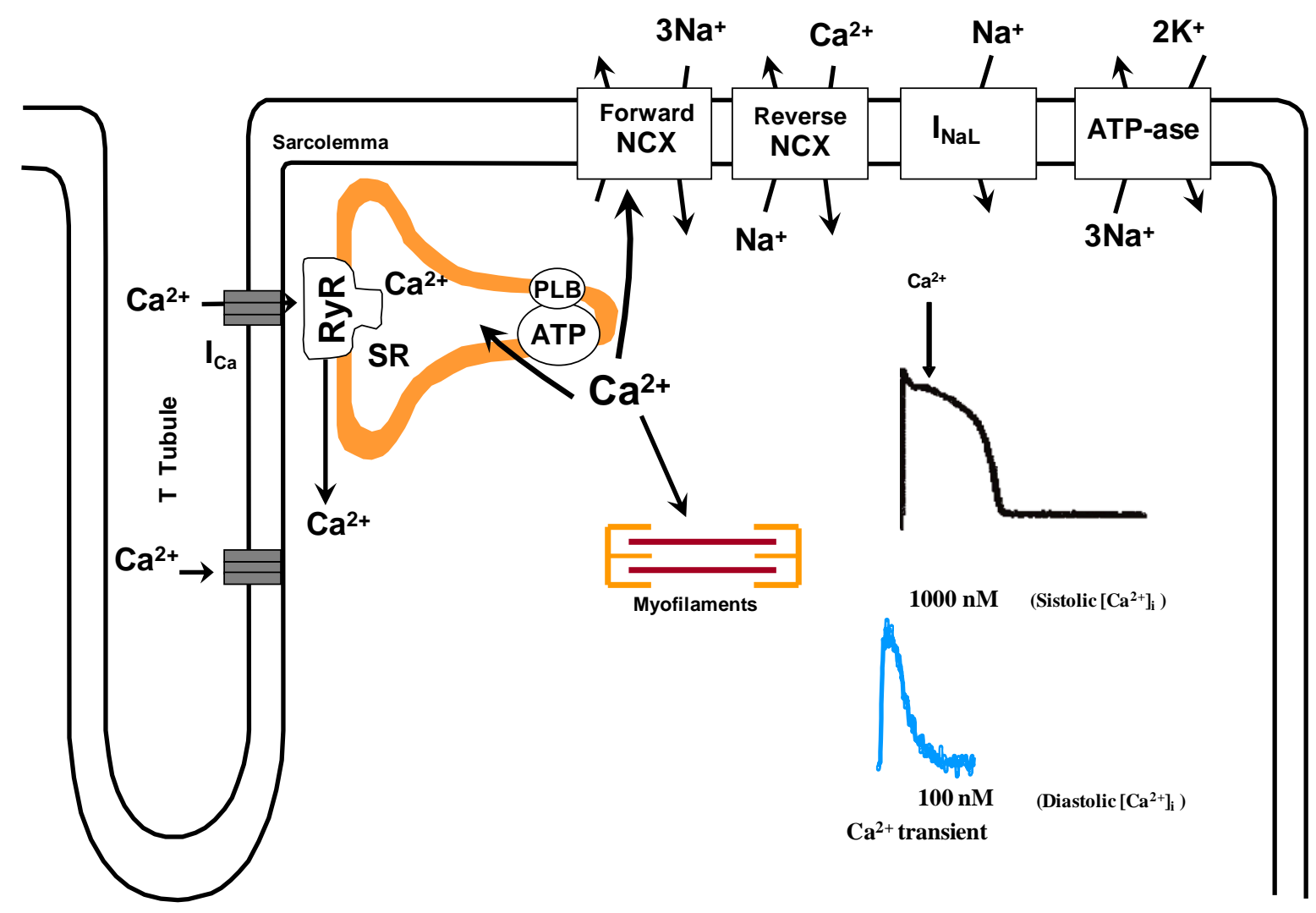

Fig.1.: Ion channels, and transporters contributing in intracellular $\mathrm{Ca}^{2+}$ and $\mathrm{Na}^{+}$ movements in cardiomyocytes. In the right part of the figure the optically measured $\left[\mathrm{Ca}^{2+}\right]_{\mathrm{i}}$ transient $\left(\mathrm{Ca}^{2+}\right.$ release from the $\left.\mathrm{SR}\right)$ is depicted. Detailed description can be found in section 1.1.1 and 1.1.2. (Modified from Bers [4.].)

Binding of calcium to troponin $\mathrm{C}$ in the contractile apparatus initiates muscle contraction (systole). Reuptake of calcium into the sarcoplasmic reticulum by the 
phospholamban-regulated sarcoplasmic reticulum $\mathrm{Ca}^{2+}$-ATPase (SERCA) allows for cardiac relaxation (diastole). $\beta$ receptor-mediated protein kinase A (PKA) stimulation regulates this $\mathrm{Ca}^{2+}$ cycling by phosphorylating L-type $\mathrm{Ca}^{2+}$ channels, RyR, and phospholamban. In normal hearts, sympathetic stimulation activates $\beta_{1}$-adrenergic receptor, which in turn stimulates the production of cAMP and thereby activates PKA. PKA phosphorylates phospholamban and RyR, both of which contribute to an increased intracellular $\left[\mathrm{Ca}^{2+}\right]_{\mathrm{i}}$ transient [4-5]. Beside to these channels, NCX plays an essential role in removal of $\mathrm{Ca}^{2+}$, also contributes to the $\mathrm{Ca}^{2+}$ trigger. The cardiac contractility and force development depend on the free intracellular $\mathrm{Ca}^{2+}$ level and the $\mathrm{Ca}^{2+}$ sensitivity of the cardiomyocytes. SERCA and the NCX play key roles in maintaining the balance of the cellular $\mathrm{Ca}^{2+}$ homeostasis. Importantly, the role of $\mathrm{NCX}$ can profoundly increase in pathological circumstances, which may result in cellular $\mathrm{Ca}$ imbalance. Any major and chronic imbalance in $\mathrm{Ca}^{2+}$ handling, exceeding the physiological shifts in $\left[\mathrm{Ca}^{2+}\right]_{\mathrm{i}}$, may result in gradual cellular $\left[\mathrm{Ca}^{2+}\right]_{i}$ overload, leading to highly increased arrhythmia propensity, or cell injury.

\subsubsection{Regulation of intracellular $\mathrm{Na}^{+}$}

In steady-state conditions intracellular $\mathrm{Na}^{+}$is determined by the balance between $\mathrm{Na}^{+}$influx and efflux. There are four major pathways for $\mathrm{Na}^{+}$influx: 1. Voltage-gate $\mathrm{Na}^{+}$ channels, 2. $\mathrm{Na}^{+} / \mathrm{H}^{+}$exchange (NHE), 3. $\mathrm{Na}^{+}-\mathrm{HCO}_{3}{ }^{-}$cotransporter $(\mathrm{NBC}), 4 . \mathrm{Na}^{+} / \mathrm{Ca}^{2+}$ exchange. Intracellular $\mathrm{Na}^{+}$concentration and $\mathrm{Na}^{+}$pump activity belong to the most important factors of the NCX regulation. Indeed, in experimental models of heart diseases associated with increased internal $\mathrm{Na}$ level (for example in ischemia/reperfusion injury), activity of NCX can be significantly elevated, which can contribute to the cellular the $\left[\mathrm{Ca}^{2+}\right]_{\mathrm{i}}$ overload. Moreover, intracellular $\mathrm{Na}^{+}$plays an important role in regulating the $\mathrm{pH}$ via the $\mathrm{Na}^{+} / \mathrm{H}^{+}$exchange and $\mathrm{Na}^{+}-\mathrm{HCO}_{3}$ - cotransporter [5].

The sarcolemmal $\mathrm{Na}^{+} / \mathrm{K}^{+}$ATP-ase activity is essential for the $\mathrm{Na}^{+}$gradient that drives ion transport processes critical for normal cardiac function. This pump transports 3 $\mathrm{Na}^{+}$and $2 \mathrm{~K}^{+}$against their electromechanical gradients for each ATP hydrolysed, maintaining the low intracellular $\mathrm{Na}^{+}$level and the high $\mathrm{K}^{+}$level. That is the reason why the $\mathrm{Na}^{+} / \mathrm{K}^{+}$ATP-ase is very important in the cardiac myocytes. The transsarcolemmal $\mathrm{Na}^{+}$ gradient established by the $\mathrm{Na}^{+}$pump activity is important for AP depolarization and regulation of NCX. More detailed studies revealed that the $\mathrm{Na}^{+}$efflux through the pump maintains the low subsarcolemmal $\mathrm{Na}^{+}$level, establishing a functional interaction between 
the $\mathrm{Na}^{+} / \mathrm{K}^{+}$ATP-ase and the NCX activity Fig.1. The rise in $\left[\mathrm{Na}^{+}\right]_{\mathrm{i}}$ occurs in the face of greater $\mathrm{Na}^{+}$influx due to more frequent and larger $\mathrm{Na}^{+}$current and enhanced $\mathrm{Na}^{+}$entry via NCX which has to extrude more $\mathrm{Ca}^{2+}$ to balance the larger $\mathrm{Ca}^{2+}$ entry via L-type $\mathrm{Ca}^{2+}$ channels. Enhanced $\mathrm{Na}^{+}$influx could also raise $\left[\mathrm{Na}^{+}\right]_{i}$, and this explains the higher $\left[\mathrm{Na}^{+}\right]_{i}$ in ventricular myocytes. $\mathrm{Na}^{+}$influx through the pump may also have changes in NCX activity, because the pump may functionally interact with NCX [6]. Alteration in intracellular $\mathrm{Na}^{+}$concentration during diastole and higher intracellular $\mathrm{Na}^{+}$concentration in cardiomyocytes can activate the reverse mode of NCX and causes an elevated intracellular $\mathrm{Ca}^{2+}$ concentration which can result in the $\left[\mathrm{Ca}^{2+}\right]_{\mathrm{i}}$ overload and cardiac injury. Thus, intracellular $\mathrm{Na}^{+}$plays an important role in the intracellular Ca balance and presents an important factor in the excitation-contraction coupling (ECC).

Moreover the late $\mathrm{Na}^{+}$current $\left(\mathrm{I}_{\mathrm{NaL}}\right)$ influences the cardiac action potential repolarization, participates in $\mathrm{Na}^{+}$and $\mathrm{Ca}^{2+}$ homeostasis of cardiac cells, and can promote arrhythmogenic activities [7-8]. Upregulation of $\mathrm{I}_{\mathrm{NaL}}$ increases intracellular $\mathrm{Na}^{+}$ concentration which causes in the SR the $\left[\mathrm{Ca}^{2+}\right]_{\mathrm{i}}$ overload. SR $\left[\mathrm{Ca}^{2+}\right]_{\mathrm{i}}$ overload then causes spontaneous $\mathrm{Ca}^{2+}$ release from SR which drives forward mode of NCX to depolarize the membrane. Furthermore the plateau phase of the AP has an important role in maintaining the $\mathrm{I}_{\mathrm{NaL}}$.

\subsection{Regulation of the NCX by intracellular $\mathrm{Ca}^{2+}$ and $\mathrm{Na}^{+}$concentrations}

The primarily role of the NCX is to pump $\mathrm{Ca}^{2+}$ out of cell using $\mathrm{Na}^{+}$concentration gradient across the cell membrane. The driving force of NCX determines the kinetics of the NCX during an action potential governed by the $\left[\mathrm{Na}^{+}\right]$and $\left[\mathrm{Ca}^{2+}\right]$ levels (both intracellular and extracellular) and actual membrane potential (Fig.2). During the rapid upstroke of AP, when the $\left[\mathrm{Ca}^{2+}\right]_{\mathrm{i}}$ is low, but the membran is depolarized, the NCX operates in its reverse mode, causing $\mathrm{Ca}^{2+}$ influx. When $\mathrm{Ca}^{2+}$ releases form the $\mathrm{SR}$, the high $\left[\mathrm{Ca}^{2+}\right]_{\mathrm{i}}$ turns the NCX kinetics in forward mode to extrude $\left[\mathrm{Ca}^{2+}\right]_{\mathrm{i}}[9]$.

Under pathological conditions, the $\left[\mathrm{Na}^{+}\right]_{\mathrm{i}}$ can be markedly increased causing considerable shift in the driving force of the NCX thus the $\mathrm{Ca}^{2+}$ influx via reverse mode can lead to the $\left[\mathrm{Ca}^{2+}\right]_{\mathrm{i}}$ overload and arrhythmogenic diastolic releases. 


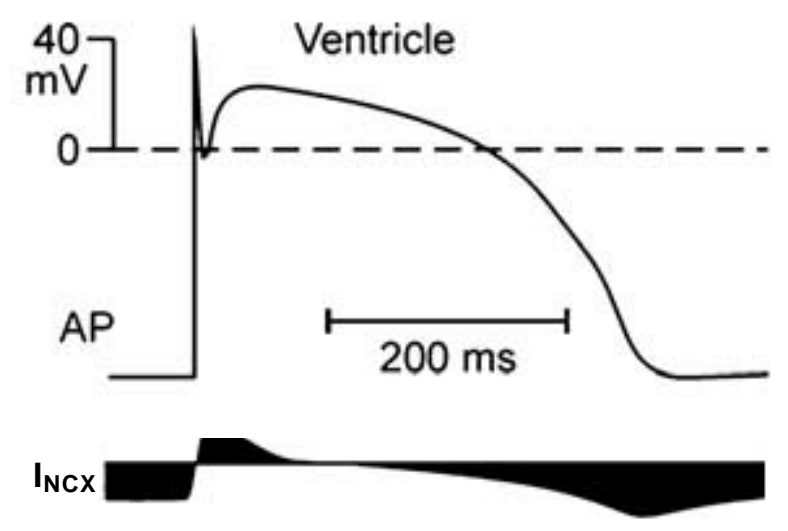

Fig.2.: Schematic presentation of $I_{N C X}$ during AP. Normal ventricular action potential and the corresponding NCX current are shown in the upper and lower part of the figure, respecively. The outward current (= reverse mode NCX transport) is only present in the early phase of the AP. $I_{N C X}$ is an inward curren (= forward mode NCX transport) during most of the the AP.

Outward NCX current is present only in the very early phase of the AP, and during the ventricular AP the NCX current is mostly an inward current, which reflects the $\mathrm{Ca}$ extrusion via NCX. Thus, NCX works almost exclusively in the $\mathrm{Ca}^{2+}$ extrusion mode, driven mostly by the high subsarcolemmal $\left[\mathrm{Ca}^{2+}\right]_{\mathrm{i}}$ transient. The driving force of NCX depends on $\mathrm{Na}^{+}$and $\mathrm{Ca}^{2+}$ concentrations at either side of the plasma membrane. Furthermore, the actual value of the membrane potential is also critical in determinig the direction of the NCX operation, with positive potential at the beginning of the AP favoring the reverse mode. In contrast, negative membrane potential at the end of the AP favours the forward mode activity. NCX is electrogenic and carries inward (depolarizing) current in forward mode and outward (repolarizing) current in reverse mode [9].

Molecular structure of NCX : NCX consist of three isoforms of a multigene family, NCX1, NCX2, NCX3. These isoforms have a very similar molecular structure. NCX1 is a $110 \mathrm{kDa}$ (Fig.3) protein expressed particularly in cardiac muscle and brain. NCX2 and NCX3 are expressed in other tissues. Although recent research revealed many details of the NCX structure its exact operation is still not completely understood [10] 


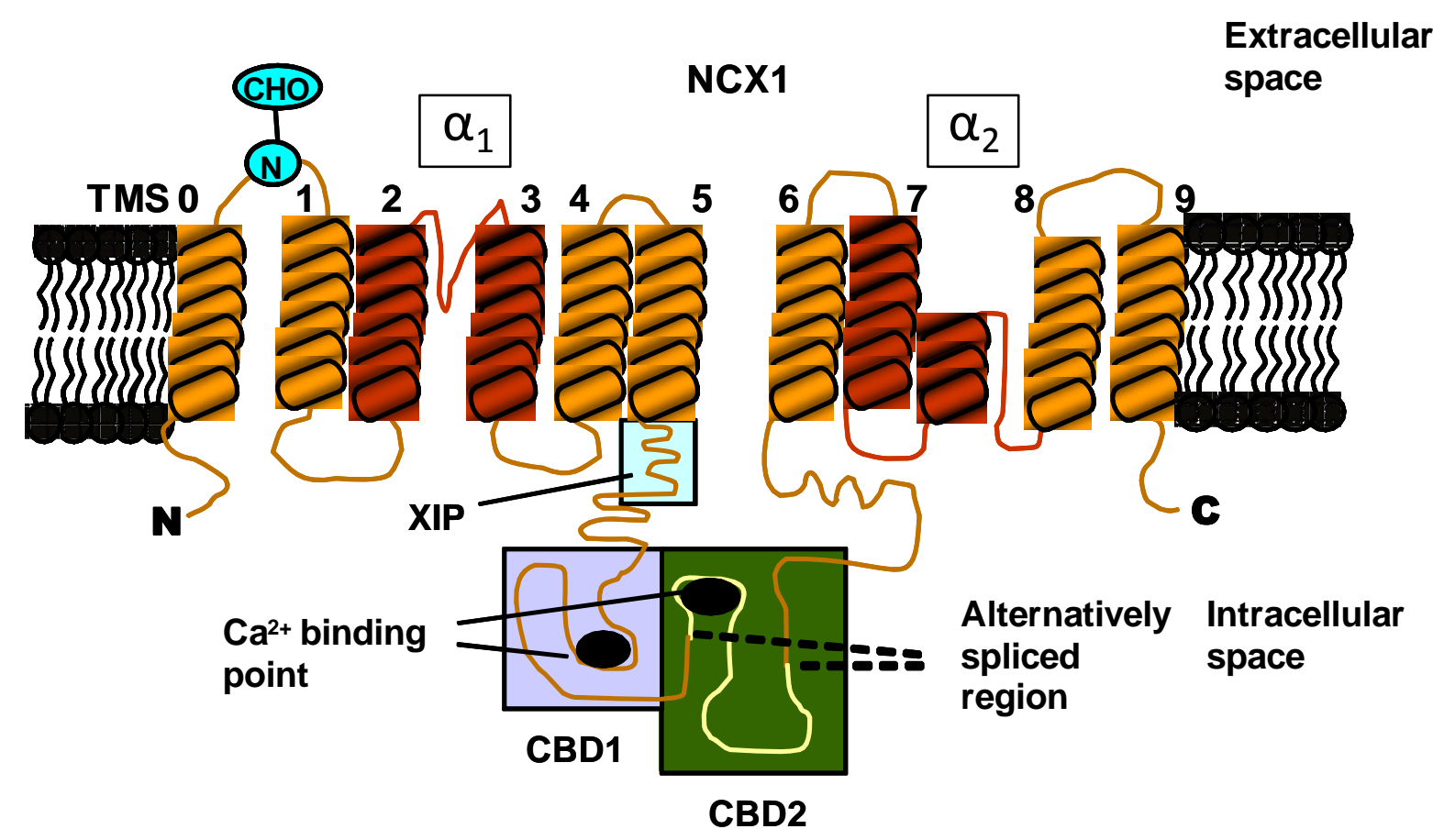

Fig.3.: The schematic molecular structure of NCX. The molecule contains four transmembrane segments, a P-loop domain, and the second $\alpha$ repeat $(\alpha-2)$. The central regions of the two $\alpha$ repeats facing opposite in the membrane and contain amino acids that are essential for normal NCX function. The two CBD domains are different (CBD1, CBD2). CBD1 binds four $\mathrm{Ca}^{2+}$ ions with high affinity [11] and $\mathrm{Ca}^{2+}$ binding is thought to be followed by a major conformational change responsible probably for the regulatory action of $\mathrm{Ca}^{2+}$ on NCX. CBD2 contains the variable alternative splicing region, as an essential structural unit [12].

\subsection{Cardiac action potential}

The cardiac action potential represents the time course of the cardiac transmembrane potential, and it is a key determinant of the cardiac electrical activity, which is shaped by several ionic currents and transporters (Fig.4)

The cardiac AP is consisted of four different phases:

Phase 0 : Rapid Depolarization

Once a stimulus is delivered to excitable cells, this evokes an action potential that is characterized by an abrupt change in voltage leading to "depolarization" of these cells due to opening of the fast $\mathrm{Na}^{+}$channels. The upstroke of the cardiac action potential is due to the sudden increase in conductance of the membrane to $\mathrm{Na}^{+}$, mediated by opening of the fast, voltage gated Na channels. 


\section{Phase 1 : Early Rapid Repolarization}

The membrane repolarizes quickly and transiently to nearly $0 \mathrm{mV}$ due to the inactivation of the sodium current, $\mathrm{I}_{\mathrm{Na}}$, and the activation of the transient outward $\mathrm{K}^{+}$current (Ito). This current is rapidly activated by the depolarized membrane voltage and increases conductance to $\mathrm{K}^{+}$along its electrochemical gradient. The $\mathrm{Ca}^{2+}$ activated chloride current, $\mathrm{I}_{\mathrm{Cl}, \mathrm{Ca}}$, also contributes to the total outward current during Phase 1, promoting the early repolarization. Furthermore, the $\mathrm{Na}^{+} / \mathrm{Ca}^{2+}$ exchanger operating in reverse mode, also produces an outward $\mathrm{Na}^{+}$current during this phase [13].

\section{$>$ Phase 2:Plateau Phase}

In this phase the plateau voltage is maintained by the balance between the outward $\left(\mathrm{K}^{+}\right.$and $\mathrm{Cl}^{-}$currents) and inward currents. The major components of the latter are the $\mathrm{Ca}^{2+}$ current via the L-type $\mathrm{Ca}^{2+}$ channel and $\mathrm{Na}^{+}$current via the NCX forward mode operation. In Phase $2, \mathrm{~K}^{+}$conductance reaches almost a standstill despite the large electrochemical gradient for $\mathrm{K}^{+}$ions at this plateau voltage [14-15].

\section{> Phase 3 : Final Rapid Repolarization}

During this final phase of the action potential before cells return back to the resting membrane potential, repolarization occurs rapidly via two currents: a time-dependent inactivation of the L-type $\mathrm{Ca}^{2+}$ channel, $\mathrm{I}_{\mathrm{CaL}}$, and activation of the repolarizing $\mathrm{K}^{+}$currents, the slow and rapid delayed rectifiers, $\mathrm{I}_{\mathrm{Ks}}$ and $\mathrm{I}_{\mathrm{Kr}}$, and the inwardly rectifying $\mathrm{K}^{+}$currents, $\mathrm{I}_{\mathrm{K} 1}$. This results in an increase in the movement of positive ions out of the cell and a return to the resting membrane potential seen in Phase 4 of the action potential. In atrial myocytes, the acetil-cholin sensitive $\mathrm{K}^{+}$current, $\mathrm{I}_{\mathrm{KAch}}$, and the ultra-rapid atrial delayed rectifier $\mathrm{K}^{+}$current, $\mathrm{I}_{\mathrm{Kur}}$ are also important contributors of the repolarization phase. These latter currents are investigated as potential targets for novel atrial-selective antiarrhythmic agents.

\section{Phase 4 : Resting Membrane Potential}

The intracellular space of resting cardiac myocytes is $70-80$ millivolts $(\mathrm{mV})$ more negative relative to the outside of the cell due to the distribution of the cations $\mathrm{Na}^{+}, \mathrm{K}^{+}$and $\mathrm{Ca}^{2+}$. In addition, there is an abundance of open $\mathrm{K}^{+}$channels at rest, thus the resting membrane potential approximates the equilibrium potential of $\mathrm{K}^{+}[16]$. Potassium outward current (keeping the inside of the cell negative) through open, inwardly rectifying $\mathrm{K}^{+}$channels, $\mathrm{I}_{\mathrm{K} 1}$, primarily determines the resting membrane potential in atrial, ventricular and Purkinje cells [17]. 


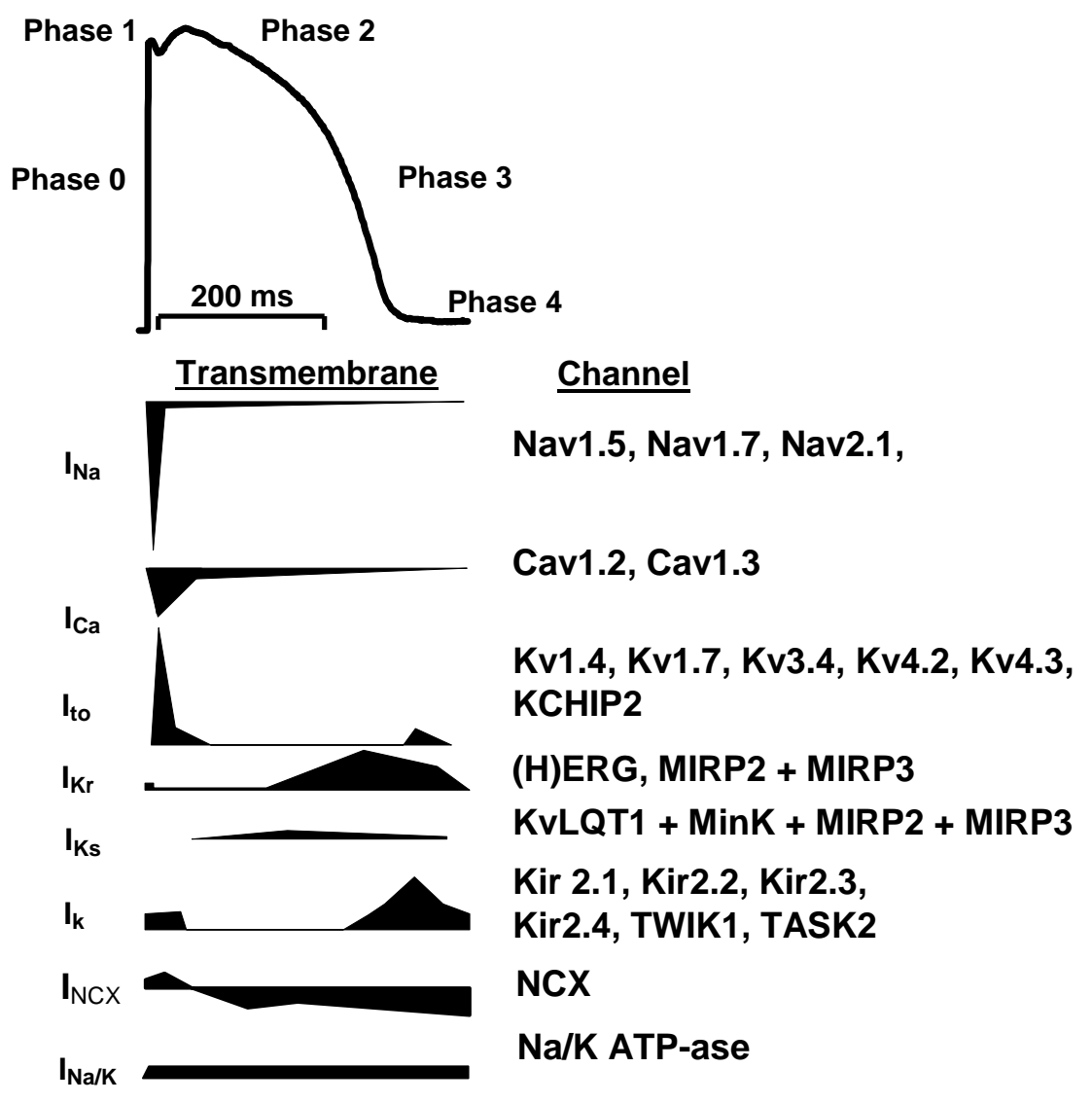

Fig.4.: The phases of the cardiac action potential and the underlying ion currents during a representative ventricular action potential.. The transmembrane ion currents are shown in the lower panel. The inward currents are depicted as downward deflections. Note that the amplitudes of the currents are not proportional with each other. The ions responsible for the currents are marked at left side of the lower panel (modified from Ravens et al [18])

\subsection{Interaction between $\mathrm{Ca}^{2+}$ homeostasis and $\mathrm{AP}$}

The cardiac AP, and consequently some related ion currents, are highly sensitive to shifts in extra- and/or intracellular $\mathrm{Ca}^{2+}$ levels. The L-type channel is the major pathway for calcium entry into the cell thus in addition to the initiation of the $\mathrm{Ca}^{2+}$ cycle its contribution to the maintaining of the plateau phase of the AP is significant. The most important connection between the $\mathrm{Ca}^{2+}$ cycle and the $\mathrm{AP}$ is the $\mathrm{Ca}^{2+}$ dependent inactivation (CDI) which is mediated by calcium binding to calmodulin (CaM) molecules. CDI could be a mechanism for the self-regulation of $\mathrm{Ca}^{2+}$ homeostasis via controlling the activity of the $\mathrm{I}_{\mathrm{CaL}}$. When $\left[\mathrm{Ca}^{2+}\right]_{\mathrm{i}}$ is high, the CDI decreases $\mathrm{I}_{\mathrm{CaL}}$ by facilitating its inactivation. Therefore the actual amount of the released $\mathrm{Ca}^{2+}$ directly modulates the $\mathrm{Ca}^{2+}$ influx 
through L-type $\mathrm{Ca}^{2+}$ channel. Consequently, this negative feed-back control is crucial in the maintenance of the beat-to-beat intracellular $\mathrm{Ca}^{2+}$ balance.

Further $\mathrm{Ca}^{2+}$ sensitive currents can also modulate the AP waveform: The delayed rectifier $\mathrm{K}^{+}$current $\left(\mathrm{I}_{\mathrm{K}}\right)$ is considered to be one of the most important transmembrane ionic currents in ventricular muscle. $\mathrm{I}_{\mathrm{K}}$ consists of two components, $\mathrm{I}_{\mathrm{Kr}}$ (rapid) and $\mathrm{I}_{\mathrm{Ks}}$ (slow). $\mathrm{I}_{\mathrm{Ks}}$ has important role during normal action potential repolarization. The $\mathrm{Ca}^{2+}$-activated chloride current, $\mathrm{I}_{\mathrm{Cl}}(\mathrm{Ca})$ can serve as a valuable indicator of local $\left[\mathrm{Ca}^{2+}\right]_{\mathrm{i}}$, promoting repolarization during Phase 1 . The $\mathrm{Ca}^{2+}$ dependent $\mathrm{K}^{+}$channels $\mathrm{I}_{\mathrm{K}(\mathrm{Ca})}$ play important role in a number of processes, involving $\mathrm{Ca}^{2+}$-dependent signaling during the AP [18].

\subsection{Effect of ischemia/reperfusion in cardiomyocytes}

Myocardial ischemia has a major consequence: it is acidosis and this contributes to the ischemic decline in force, in large part for decreased myofilament $\mathrm{Ca}^{2+}$ sensitivity. $\left[\mathrm{Ca}^{2+}\right]_{\mathrm{i}}$ transient amplitude can be initially decreased. Ischemia can also increase diastolic $\left[\mathrm{Ca}^{2+}\right]_{\mathrm{i}}$. Low intracellular $\mathrm{pH}$ stimulates proton extrusion via NHE (and NBC), that is the reason why $\mathrm{Na}^{+}$influx is increased. Furthermore, the $\mathrm{Na}^{+} / \mathrm{K}^{+}$pump is partially inhibited at low $\mathrm{pH}$. These factors lead to the slow recovery of contractility via shift in NCX and increase in $\left[\mathrm{Ca}^{2+}\right]_{\mathrm{i}}$ and could also lead to $\left[\mathrm{Ca}^{2+}\right]_{\mathrm{i}}$ overload and arrhythmias. $\left[\mathrm{Ca}^{2+}\right]_{\mathrm{i}}$ overload can lead to cell necrosis during the reperfusion period. Increase in $\left[\mathrm{Ca}^{2+}\right]_{i}$ and oxidative stress-induced dysfunction of sarcoplasmic reticulum are the reasons for cell damage during reperfusion. These also contribute to the pathogenesis of ischemia/reperfusion induced injury. During ischemia the major way of $\mathrm{Ca}^{2+}$ entry is reverse mode NCX, due to sarcolemmal depolarization and increased intracellular $\mathrm{Na}^{+}$ concentration. In fact, decreased ATP phosphorylation potential blocks the activity of the sarcolemmal $\mathrm{Na}^{+} / \mathrm{K}^{+}$ATPase, the intracellular $\mathrm{Na}^{+}$concentration rises and the sarcolemma is being depolarized. Cytosolic $\left[\mathrm{Na}^{+}\right]$overload is accentuated by intracellular acidosis, which induces $\mathrm{Na}^{+}$entry through the NHE. The ischemia associated acidosis contributes to increase cytosolic $\mathrm{Ca}^{2+}$ induced by the NHE, which is strongly coupled to NCX, so that in long term the cytosolic $\mathrm{H}^{+}$is exchanged with extracellular $\mathrm{Ca}^{2+}$ [23-24]. Inhibitors of the $\mathrm{Na}^{+} / \mathrm{H}^{+}$exchanger were found to be protective if used before ischemia, while their effectiveness was reduced when given during the reperfusion phase [25-26]. 


\subsection{The future perspectives of NCX modulation}

Since pharmacological inhibition of the NCX exchanger proved to be beneficial in experimental models of cardiac disorders [27], selective NCX inhibitors may represent a novel group for the treatment of cardiac diseases. For example, intracellular accumulation of $\mathrm{Na}^{+}$in the myocardium during ischemia/reperfusion favors the reverse mode operation of NCX, which may contribute to the intracellular accumulation of $\mathrm{Ca}^{2+}$ leading to cell damage and death [28-29]. Therefore, pharmacological inhibition of NCX by ORM -10103 may provide cardioprotection by restricting excessive $\mathrm{Ca}^{2+}$ accumulation via inhibition of the reverse mode operation of NCX [30].

Prolongation of the QT interval is a severe risk factor in a number of cardiovascular diseases. Two of the genes responsible for long QT syndrome (LQTS), have been identified as KCNH2 (LQT2) and SCN5A (LQT3) [31.]. ATX-II is an inhibitor of sodiumchannel inactivation that thereby mimics LQT3, in which a mutation in SCN5A leads to a small, persistent component of the inward, depolarizing ion current $\left(\mathrm{I}_{\mathrm{Na}}\right)$ via continuous reopening of the sodium channel. $I_{\mathrm{Na}}$ is responsible for rapid initial action potential depolarization. Furthermore abnormalities in $I_{\mathrm{Na}}$ inactivation produce large inward $\mathrm{Na}^{+}$ currents during the cardiac action potential plateau, causing arrhythmias [32]. Against increased $\mathrm{I}_{\mathrm{NaL}}$ induced pathologic alterations in $\left[\mathrm{Ca}^{2+}\right]_{\mathrm{i}}$ homeostasis selective NCX inhibition by ORM-10103 could be highly protective.

The major problem, however, with the currently available NCX inhibitors is the lack of their selectivity. Concomitant inhibition of the L-type $\mathrm{Ca}^{2+}$ current is the most important limitation of their use in experimental studies. Although combined block of $\mathrm{I}_{\mathrm{CaL}}$ and $\mathrm{I}_{\mathrm{NCX}}$ can also be useful in certain clinical settings, it makes difficult to interpret the beneficial effects of the pure NCX inhibition. Therefore, experimental use of the newly developed, selective NCX inhibitors is a major advancement in the field of the NCX research. 


\subsection{Aims of the study}

The principal aim of the study was to directly study how partial inhibition of the $\mathrm{Na}^{+} / \mathrm{Ca}^{2+}$ exchanger via the novel, selective pharmacological agent ORM-10103 influences the elements of $\mathrm{Ca}$ handling in cardiac cells. Our results describe the effect of the application ORM -10103 in dog ventricular cells under increased intracellular $\mathrm{Ca}^{2+}$ level.

The aims of this study were:

$>$ To investigate the protective effect of a novel, selective NCX inhibitor ORM-10103 against the adverse effects of pharmacologically induced $\mathrm{Na}^{+}$-induced $\mathrm{Ca}^{2+}$ load.

To establish a cellular level ischemia/reperfusion injury model (moderate and severe ischemia), in which we can characterize the survival rate of the cells, as well as the major electrophysiological parameters of AP and CaT.

To estimate the potential therapeutic possibilities of selective NCX inhibition against adverse effects of ischemia reperfusion injury, applying ORM-10103. 


\section{MATERIALS AND METHODS}

All animal experiments were carried out in compliance with the Guide for the Care and Use of Laboratory Animals (USA NIH publication NO 86-23, revised 1996) and conformed to Directive 2010/63/EU of the European Parliament. Furthermore, all experimental protocols were approved by the Ethical Committee for Protection of Animals in Research of the University of Szeged, Hungary (permit No. I-74-9/2009).

\subsection{Isolation of canine left ventricular cardiomyocytes}

Canine ventricular cardiomyocytes were isolated from adult mongrel dogs of either sex weighing 10 to $20 \mathrm{~kg}$. Following sedation (xylazine, $1 \mathrm{mg} / \mathrm{kg}$, i.v.) the animals were anaesthetized with $30 \mathrm{mg} / \mathrm{kg}$ thiopental and anticoagulated with sodium-heparin. The proper depth of anesthesia was carefully tested with pupil and pain reflexes. After right lateral thoracotomy the heart was quickly removed and immediately rinsed in oxygenated modified Locke's solution containing (in $\mathrm{mM}$ ): $\mathrm{Na}^{+} 140, \mathrm{~K}^{+} 4, \mathrm{Ca}^{2+} 1.0, \mathrm{Mg}^{2+} 1, \mathrm{Cl}-126$, $\mathrm{HCO}_{3}-25$ and glucose 11 . The $\mathrm{pH}$ of the solution, bubbled with $95 \% \mathrm{O}_{2}$ and $5 \% \mathrm{CO}_{2}$ at $37^{\circ} \mathrm{C}$, ranged from 7.35 to 7.45 . Excised left ventricular segments were perfused at $37^{\circ} \mathrm{C}$ through the anterior descending coronary artery using a gravity flow Langendorff apparatus. First, to remove the blood the heart was washed for $5 \mathrm{~min}$ with isolation solution containing $1 \mathrm{mM} \mathrm{Ca}^{2+}$, than the perfusate was switched to a $\mathrm{Ca}^{2+}$-free solution containing (in mM) $135 \mathrm{NaCl}, 4.7 \mathrm{KCl}, 1.2 \mathrm{KH}_{2} \mathrm{PO}_{4}, 1.2 \mathrm{MgSO}_{4}, 10 \mathrm{HEPES}, 10$ glucose, 20 taurine, $4.4 \mathrm{NaHCO}_{3}$, and $5 \mathrm{Na}$-Pyruvate (pH 7.2 with $\mathrm{NaOH}$ ). 10 min later, $75 \mu \mathrm{M}$ $\mathrm{CaCl}_{2}$ and $150 \mathrm{U} / \mathrm{ml}$ collagenase (Worthington Type II), and 15 min later $0.35 \mathrm{U} / \mathrm{ml}$ protease (Sigma Type XIV) was added to the perfusate. Cell dissociation lasted for 30-40 min. At the end of this isolation process the tissue was minced and gently agitated. The myocytes were harvested and stored in the isolation solution containing $1 \mathrm{mM} \mathrm{Ca}^{2+}$ at room temperature for the same day or at $4{ }^{\circ} \mathrm{C}$ for next day recordings. Following restoration of the external $\left[\mathrm{Ca}^{2+}\right]$ at least $60 \%$ of the cardiomyocytes were rod-shaped showing clear striation. During measurements the cells were perfused with Tyrode solution. The Tyrode solution contained (in $\mathrm{mM}$ ): $144 \mathrm{NaCl}, 0.4 \mathrm{NaH}_{2} \mathrm{PO}_{4}, 4 \mathrm{KCl}, 0.53$ $\mathrm{MgSO}_{4}, 1.8 \mathrm{CaCl}_{2}, 5.5$ glucose and 5 HEPES. The $\mathrm{pH}$ was set to 7.4 with $\mathrm{NaOH}$. All measurements were performed at $37^{\circ} \mathrm{C}$. 


\subsection{Determination of cell viability}

Freshly isolated, unloaded cardiomyocytes, subjected to the ischemia/reperfusion protocol were visually assessed, classified and counted in randomly selected microscopic fields (Olympus IX 71 inverted fluorescence microscope; 20x objective). A representative, circular region of the microscopic field (region of interest; ROI), containing predominantly contracting cells, was used for analysis. Still images of the ROI were periodically captured by an Olympus digital photo camera (C-7070). In order to safely distinguish living and dead cells, instead of using vital dyes, we followed another, similarly effective classification, utilizing characteristic morphological variables, i.e. the shape and visibility of striation of the cells. These data principally differ from those shown in all other figures. The reason is that other figures only contain data determined in surviving cells, i.e. all those cells survived the full ischemia/reperfusion protocol. However, usually a substantial fraction of cells, especially in the nontreated groups did not survive the protocol and their incomplete datasets were not considered for statistical analysis. Instead of using vital dyes, we followed a similarly effective classification, based simply on the shape and visibility of the striation of the cell [29]. This form of classification may also have some benefits since with proper experience one is able to reliably dissect crippled, dying cardiomyocytes from safely surviving cells. Cardiomyocytes in the ROI were divided into two classes: Class A: cells with normal (not significantly shortened) shape, intact border and visible striation; Class B: cells dead or at the verge of death, in severe contracture, parallel striation cannot be observed. The cells were stimulated $(1 \mathrm{~Hz})$ throughout the experiment. The number of surviving and dead cells was determined several times (at $0,1.5^{\text {th }}, 3^{\text {rd }}, 4^{\text {th }}, 10^{\text {th }}, 15^{\text {th }}, 23^{\text {th }}, 24$ ${ }^{\text {th }}, 26^{\text {th }}, 30^{\text {th }}, 32^{\text {nd }}$ minutes) during the ischemia/reperfusion protocol.

\subsection{Validation of the simulated ischemia via NADH measurements}

Parallel to the shift from aerobic to anaerobic metabolism a substantial fraction of the intramitochondrial $\mathrm{NAD}^{+}$content is gradually reduced. Since only the reduced form, $\mathrm{NADH}$ is fluorescent, a raise in $[\mathrm{NADH}]_{\mathrm{m}}$ is considered as a direct indicator of ischemia. In this set of experiments NADH was excited at $360 \mathrm{~nm}$, while the native cellular fluorescence was monitored at 450nm. The relative magnitude of the momentary fluorescent shift compared to the maximal raise achieved following the application of $10 \mathrm{mM} \mathrm{NaCN}$ has been used to characterize the level of ischemia. Therefore, cardiomyocytes were stimulated at $1 \mathrm{~Hz}$ and the simulated ischemia/reperfusion protocol 
(i.e. 3-5 min normoxic control, 20 min simulated ischemia and 10 min reperfusion - see details below) was used. At the end of the protocol the cells were exposed to $10 \mathrm{mM}$ cyanide, which quickly induced maximal $\mathrm{NAD}^{+}$reduction. During these measurements $\mathrm{pO}_{2}$ levels were repetitively determined using a blood gas analyzer (ABL 505, Radiometer, Denmark) in $50 \mu \mathrm{l}$ samples collected from the central area of the chamber.

\subsection{Measuring $\left[\mathrm{Ca}^{2+}\right]_{\mathrm{i}}$ transients in single ventricular cardiomyocytes}

Fluorescence measurements were performed on the stage of an Olympus IX 71 inverted fluorescence microscope. $\left[\mathrm{Ca}^{2+}\right]_{\mathrm{i}}$ transients were monitored using a $\mathrm{Ca}^{2+}$-sensitive fluorescent dye, Fluo 4. Isolated cardiomyocytes were loaded with $6 \mu \mathrm{M}$ Fluo 4-AM (AM is the membrane permeable acetoxymethyl ester conjugated form of the dye) for 15 minutes at room temperature in dark. The dye was excited at $480 \mathrm{~nm}$ and the emitted fluorescence was detected at $535 \mathrm{~nm}$. Loaded cells were mounted in a low volume imaging chamber (RC47FSLP, Warner Instruments) and for steady-state $\left[\mathrm{Ca}^{2+}\right]_{\mathrm{i}}$ measurements myocytes were stimulated at a constant frequency of $1 \mathrm{~Hz}$ through a pair of platinum electrodes by an electronic stimulator (Experimetria Ltd, Hungary). While the cells superfused with normal (during control and reperfusion periods) or "simulated ischemic" Tyrode solution. Optical signals were sampled at $1 \mathrm{kHz}$ and recorded by a photon counting photomultiplier module (Hamamatsu, model H7828). Data acquisition and analysis were performed using a CAIRN Optoscan System. Alterations in $\left[\mathrm{Ca}^{2+}\right]_{\mathrm{i}}$ were characterized by the corresponding changes in background corrected fluorescence normalized to the control state $\left(\mathrm{F} / \mathrm{F}_{0}\right)$. Amplitudes of the $\left[\mathrm{Ca}^{2+}\right]_{\mathrm{i}}$ transients were calculated as differences between systolic and diastolic values. Diastolic $\left[\mathrm{Ca}^{2+}\right]_{\mathrm{i}}\left(\left[\mathrm{Ca}^{2+}\right]_{\mathrm{iD}}\right)$ levels were determined immediately before the onset of the stimulus. Systolic $\left[\mathrm{Ca}^{2+}\right]_{\mathrm{i}}$ was determined at the peak of the corresponding transient. $\left[\mathrm{Ca}^{2+}\right]_{\mathrm{i}}$ changes were expressed as fluorescence measured over basal unstimulated fluorescence $\left(\mathrm{F} / \mathrm{F}_{0}\right)$. Background fluorescence levels were recorded for a few times during each experiment and were used to correct raw fluorescence data.

\subsection{Monitoring of single cell action potentials}

Single cell APs were recorded using conventional sharp microelectrodes. Selected cardiomyocytes were impaled with high-resistance (20-40 $\mathrm{M} \Omega$ ) electrodes filled with $3 \mathrm{M} \mathrm{KCl}$. APs were recorded with an Axoclamp 900A amplifier (Axon Instruments) and were analyzed using the Clampfit 10.0 software (Molecular Devices Corporation). Action 
potential parameters, like amplitude, plateau level, duration (both $\mathrm{APD}_{25}$ and $\mathrm{APD}_{90}$ ) and triangulation $\left(\mathrm{APD}_{90}-\mathrm{APD}_{25}\right)$ of the $\mathrm{AP}$, and the resting membrane potential were determined.

\subsection{Eperimental protocols}

\subsubsection{Late $\mathrm{Na}^{+}$current $\left(\mathrm{I}_{\mathrm{NaL}}\right)$ protocol}

The cardiomyocytes were loaded with Fluo 4-AM at room temperature. ATX-II ( $2 \mathrm{nM})$ [33.] has been used in $\left[\mathrm{Ca}^{2+}\right]_{i}$ transient measurements. The effect of upregulating $\mathrm{I}_{\mathrm{NaL}}$ using ATX-II, which is known to increase substantially the $\mathrm{Na}^{+}$influx due to lengthening of the inactivation of $\mathrm{I}_{\mathrm{NaL}}$. Application of $2 \mathrm{nM}$ ATX-II significantly increased the amplitude of the $\left[\mathrm{Ca}^{2+}\right]_{\mathrm{i}}$ transient. In each experiment ORM-10103 has been used in a concentration of $10 \mu \mathrm{M}$ for inhibition of the exchanger [34.].

\subsubsection{Ischemic experimental approach}

4 principal sets of experiments were performed: cell viability measurements, NADH measurements, $\left[\mathrm{Ca}^{2+}\right]_{\mathrm{i}}$ transient measurements and AP measurements.

1) Cell viability measurements: Two subsets of experiments were performed. The ischemia/reperfusion protocols were identical to the corresponding subsets of the AP measurements (native, untreated and ORM-10103 treated cardiomyocytes). Since in normoxic conditions cell survival was usually close to $100 \%$ for at least an hour, no separate time control (TC) measurements were performed.

2) $\left[\mathrm{Ca}^{2+}\right]_{i}$ transient measurements. These measurements were carried out in cardiomyocytes loaded with Fluo 4-AM. Five groups of experiments were performed. The first group was used for time control; no ischemia/reperfusion (I/R) cycle was applied. In the second one (untreated) cells were subjected to a full cycle of ischemia/reperfusion. In the third one (ORM-10103) cells were pretreated with $10 \mu \mathrm{M}$ ORM-10103 at the end of the control period but prior to the ischemia/reperfusion cycle. The fourth and fifth groups were similar to the second and third ones, with the exception that in order to substantially increase the driving force for reverse mode NCX activity these solutions also contained the $\mathrm{Na}^{+} / \mathrm{K}^{+}$-ATP-ase (NKA) inhibitor strophantidine $(1 \mu \mathrm{M})$.

3) AP measurements: Three groups of experiments were performed. The protocols were identical to the corresponding groups of the $\left[\mathrm{Ca}^{2+}\right]_{\mathrm{i}}$ transient measurements (i.e. untreated, 
ORM-10103 treated and time control), but these measurements were carried out using unloaded cardiomyocytes.

4) NADH measurements. Since NADH is inherently fluorescent, no cells in this group had to be loaded with external dye. Cardiomyocytes in the first subgroup were utilized as time control and were superfused with oxygenated Tyrode solution throughout the experiment; no simulated ischemia was introduced. The second subgroup of cells was subjected to a full cycle of ischemia/reperfusion.

\subsection{Introducing simulated ischemia}

We introduced simulated ischemia by applying an ischemic solution that mimic the different aspects of the ischemia: low $\mathrm{pH}$, low $\mathrm{pO}_{2}$, high $\mathrm{K}^{+}$, glucose free, high lactate perfusion solution (composition (in $\mathrm{mM}$ ): $123 \mathrm{NaCl}, 6 \mathrm{NaHCO}_{3}, 0.9 \mathrm{NaH}_{2} \mathrm{PO}_{4}, 8 \mathrm{KCl}, 0.5$ $\mathrm{MgSO}_{4}, 2.5 \mathrm{CaCl}_{2}$ and 20 lactate) [35]. The cells were first perfused with normal Tyrode solution (normoxia: $3 \mathrm{~min}$ ), then with simulated ischemic solution (ischemia: $20 \mathrm{~min}$ ), and finally again with normal Tyrode solution (reperfusion: $10 \mathrm{~min}$ ). During the ischemic period an oxygen-free gas combination $\left(95 \% \mathrm{~N}_{2}+5 \% \mathrm{CO}_{2}\right)$ was layered over the solution. Each cell was exposed to the ischemia/reperfusion cycle only once. The oxygen level in the ischemic solution was decreased to a very low level by heavily gassing the solution with the anoxic gas mixture. The $\mathrm{pO}_{2}$ level in the solution was periodically checked using a clinical blood gas analyzer (Radiometer ABL 505). The $\mathrm{pO}_{2}$ level was approximately 180 $\mathrm{mmHg}$ in normal Tyrode. This rapidly declined to about $32 \mathrm{mmHg}$ (determined in the chamber) in the ischemic solution, which represents a reasonably high level of hypoxia.

\subsection{Variabilities of $\mathrm{APD}_{90}, \mathrm{APD}_{25}$ and the $\left[\mathrm{Ca}^{2+}\right]_{\mathrm{i}}$ transient}

The beat-to-beat variability of $\mathrm{APD}_{90}, \mathrm{APD}_{25}$, and $\mathrm{CaT}$ amplitude were calculated by the analysis of 50 consecutive action potentials or $\left[\mathrm{Ca}^{2+}\right]_{\mathrm{i}}$ transients from the steadystate section of the experiment, via using the following formulas:

$$
\begin{aligned}
& \operatorname{BVR}\left({ }_{\mathrm{ADP}} 90\right)=\Sigma\left(\mathrm{APD}_{90} ; \mathrm{i}+1-\mathrm{APD}_{90} ; \mathrm{i}\right) /\left(\mathrm{n}_{\text {beats }} \mathrm{x} \sqrt{ } 2\right) \\
& \operatorname{BVR}\left({ }_{\mathrm{ADP} 25}\right)=\Sigma\left(\mathrm{APD}_{25} ; \mathrm{i}+1-\mathrm{APD}_{25} ; \mathrm{i}\right) /\left(\mathrm{n}_{\text {beats }} \mathrm{x} \sqrt{ } 2\right)
\end{aligned}
$$

Since the uncorrected CaT amplitude largely depends on nonspecific variables (cell size, dye concentration and leakage) and this dependence would also be reflected in the variabilities, the simple formula used to calculate short term APD variabilities may not be 
suitable to properly characterize $\mathrm{CaT}$ variabilities. Therefore, we normalized the raw variability data to the mean $\mathrm{CaT}$ amplitude $\left(\mathrm{CaT}_{\mathrm{TC}}\right)$, calculated from the corresponding time control experiments, as follows:

$\operatorname{BVR}($ CaT $)=\Sigma($ CaT amplitude;i+1- CaT amplitude; $) /\left(\left(\mathrm{n}_{\text {beats }} \mathrm{x} \sqrt{ } 2\right) \times\right.$ mean $\mathrm{CaT}_{\mathrm{TC}}$ amplitude $)$

\subsection{Drugs}

All materials were purchased from Sigma (St. Louis, Mo, USA) except for Fluo 4AM (Life Technologies). ORM-10103 was a gift from Orion Pharma (Espoo, Finland).

The chemical structure of ORM-10103 [5-nitro-2-(2-phenylchroman-6-yloxy) pyridine] [34]:

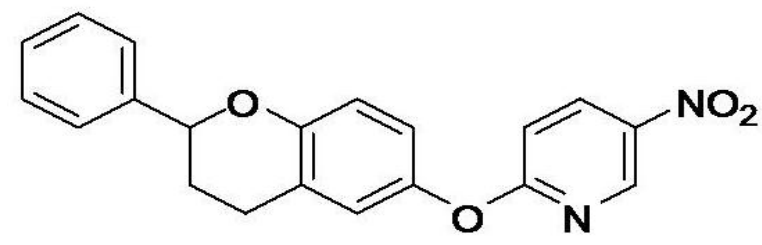

ORM-10103

\subsection{Data processing and statistics}

Individual cardiomyocytes - even if selected from the same isolation - show great variability in size and volume. Consequently, at the end of the loading process their fluorescent dye content - even at identical $\left[\mathrm{Ca}^{2+}\right]_{\mathrm{i}}$ - showed significant variations and this variability was fully reflected by the magnitude of the optical signals. Therefore, to avoid abnormally high standard deviations caused solely by the heterogeneity of the dye content, fluorescence values were normalized to the control period.

In contrast to the "survival" data shown in Fig. 8, all single cell data presented in Fig.s 5-15 were obtained from living cardiomyocytes, surviving the ischemia/reperfusion protocol. Incomplete single cell measurements were discarded from data analysis. All values presented are arithmetic means \pm S.E.M. All data were analyzed using Students $t$ test for paired or unpaired data, as relevant. Differences were considered significant when $\mathrm{P}$ was less than 0.05 . 


\section{RESULTS}

\subsection{The physiological effect of selective $\mathrm{NCX}$ inhibition on the $\left[\mathrm{Ca}^{2+}\right]_{i}$ transient}

Cardiomyocytes were loaded with a $\mathrm{Ca}^{2+}$-sensitive fluorescent dye, Fluo 4-AM. In time control measurements only a small, gradient decrease in the magnitude and baseline of the transient could be observed (Fig. 5A). This gradual decrease is predominantly a consequence of dye leakage/extrusion from the cell. Interestingly, in normoxic conditions the application of $10 \mu \mathrm{M}$ ORM-10103 had no apparent effect on the magnitude or kinetics of the transient (Fig. 5B). For selective inhibition of the exchanger, ORM-10103 has been used in $10 \mu \mathrm{M}$ dose. At this dose no apparent effect of the inhibitor on further ion transporters (except a small inhibition of $\mathrm{I}_{\mathrm{Kr}}$ ) could be observed [34]. In a predominant number of cardiomyocytes application of $10 \mu \mathrm{M}$ ORM-10103 during normoxia did not cause apparent changes in the magnitude, shape and decay kinetics of the transient.

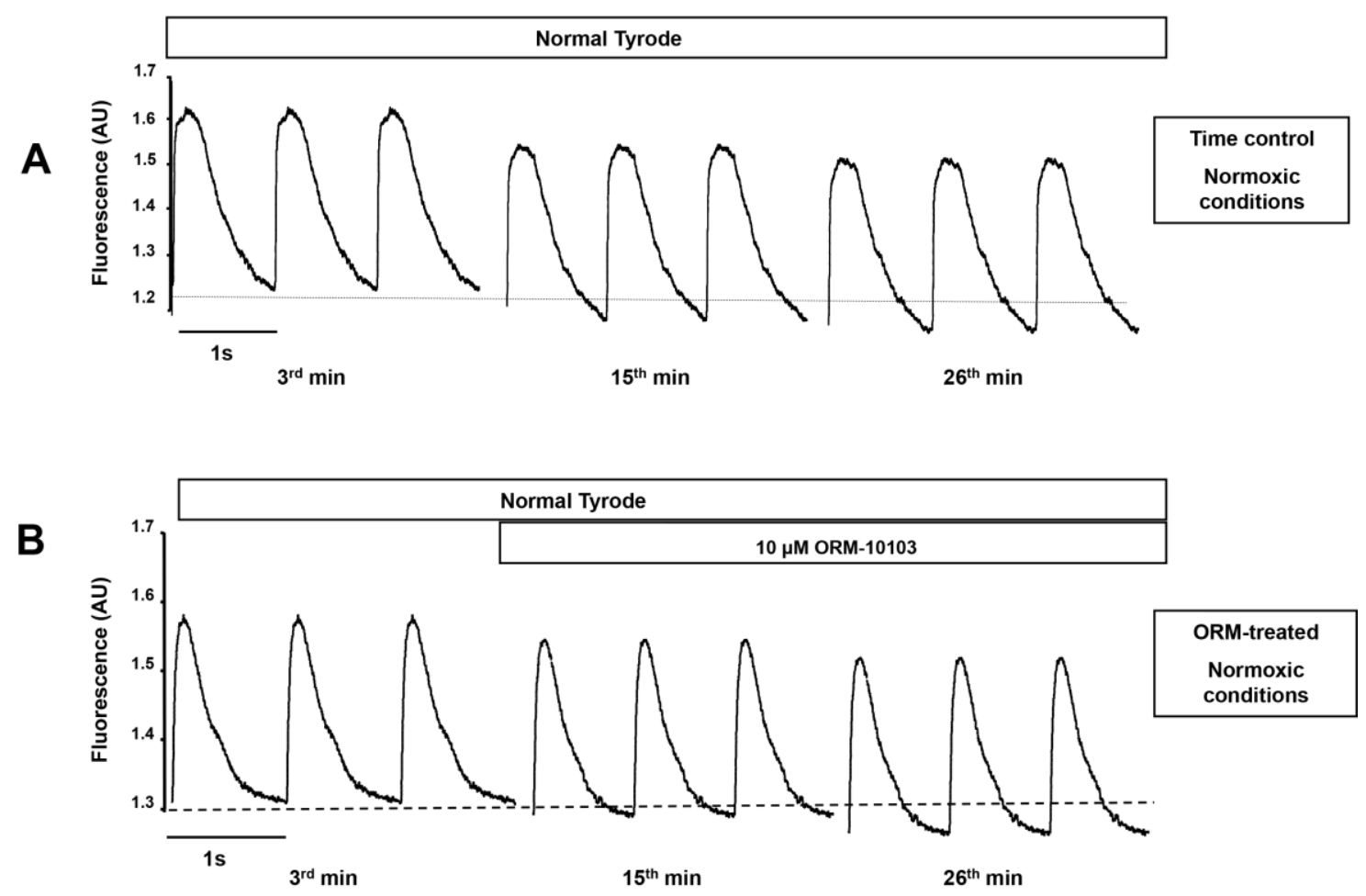

Fig.5.: Representative traces from the CaT measurements and the effect of 10 $\mu M$ ORM10103 on the $\left[\mathrm{Ca}^{2+}\right]_{\mathrm{i}}$ transient. Cardiomyocytes were loaded with a $\mathrm{Ca}^{2+}$-sensitive fluorescent dye, Fluo 4-AM. In a predominant number of cardiomyocytes application of 10 MM ORM-10103 during normoxia did not cause apparent changes in the magnitude, shape and decay kinetics of the transient $(B)$. 


\subsection{Effect of selective NCX inhibition on the $I_{N a L}$ induced increase in $\left[\mathrm{Ca}^{2+}\right]_{i}$ transient}

$\mathrm{I}_{\mathrm{NaL}}$ was activated by $2 \mathrm{nM}$ ATX-II which is known to increase substantially the $\mathrm{Na}^{+}$influx due to lengthening of the inactivation of $\mathrm{I}_{\mathrm{NaL}}$. Application of $2 \mathrm{nM}$ ATX-II significantly enhanced the magnitude of the $\left[\mathrm{Ca}^{2+}\right]_{\mathrm{i}}$ transient, but this increase was diminished by subsequent application of $10 \mu \mathrm{M}$ ORM10103 (Fig.6A). In contrast, when $10 \mu \mathrm{M}$ ORM10103 was applied as a pretreatment, the secondary administration of ATX-II failed to enhance the $\left[\mathrm{Ca}^{2+}\right]_{\mathrm{i}}$ transient (Fig.6B). Statistical significances were verified by repeated measure ANOVA.
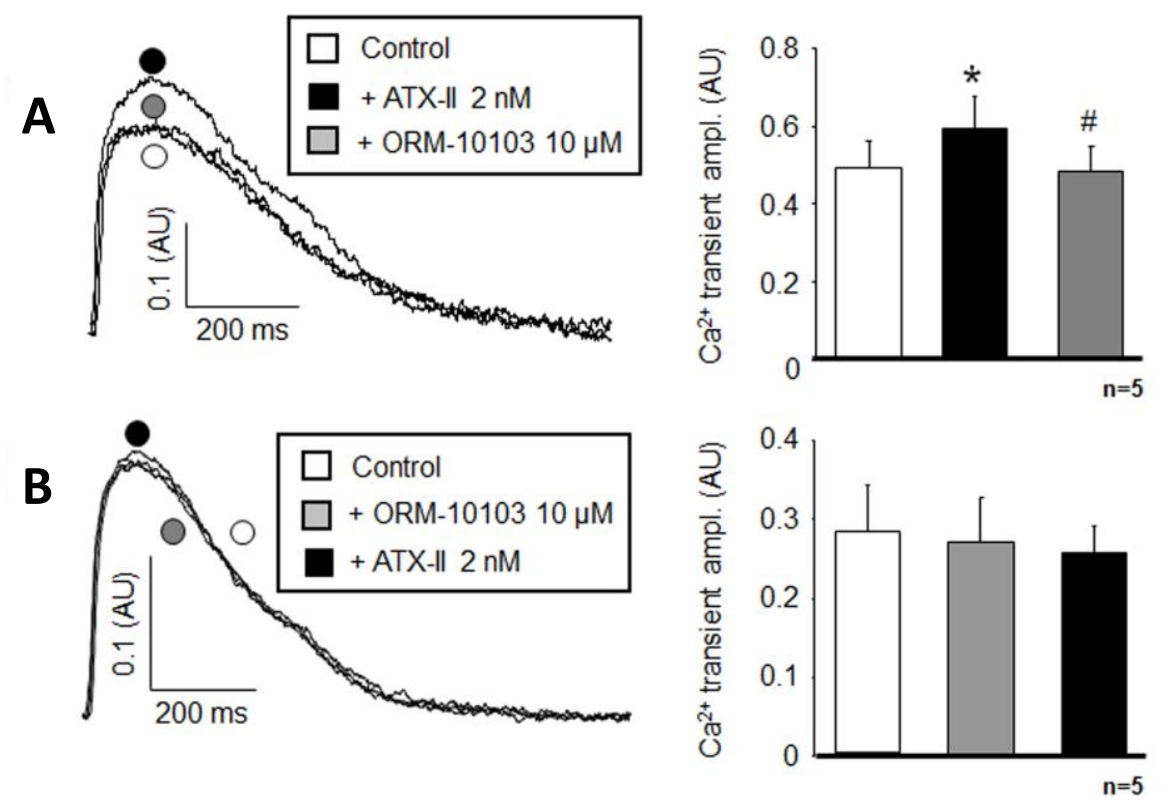

Fig.6.: The efficacy of NCX inhibition against the $I_{N a L}$ activation induced $\left[\mathrm{Ca}^{2+}\right]_{i}$ load. $2 \mathrm{nM}$ ATX-II significantly enhanced the amplitude of the $\left[\mathrm{Ca}^{2+}\right]_{\mathrm{i}}$ transient $(A)$. In contrast, when $10 \mu M$ ORM-10103 was applied first, the ATX-II induced enhencement of the $\left[\mathrm{Ca}^{2+}\right]_{\mathrm{i}}$ transient was reverted by ORM10103 (B). Columns and bars represent means \pm SEM values, asterisks denote significant differences from control $(P<0.05)$. While \# from the ATX-II treated group AU represents arbitrary units.

\subsection{ORM-10103 decreased the spontaneous diastolic $\mathrm{Ca}^{2+}$ releases evoked by $\mathrm{Na}^{+} / \mathrm{K}^{+}$ pump inhibition}

We hypothesized that ATX-II induced EADs are caused by $\mathrm{Ca}^{2+}$ release from SR (which also causes DADs), rather than by reactivation of the L-type $\mathrm{Ca}^{2+}$ current during prolonged AP (Fig.7). The pacing frequency was set to $1 \mathrm{~Hz}$. During NKA inhibition via 1 $\mu \mathrm{M}$ strophantidine resulted in significantly enhanced $\left[\mathrm{Ca}^{2+}\right]_{i}$ transient (A). Pretreatment 
with $10 \mu \mathrm{M}$ ORM10103 markedly reduced the effect of the subsequently applied strophantidine $(\mathrm{B}, \mathrm{C})$.

A
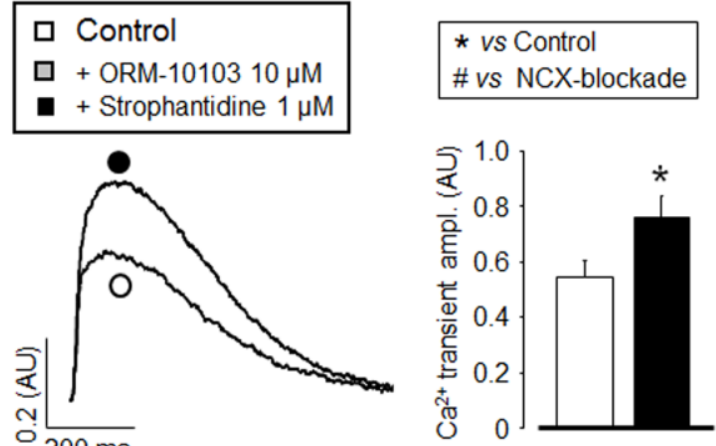

B
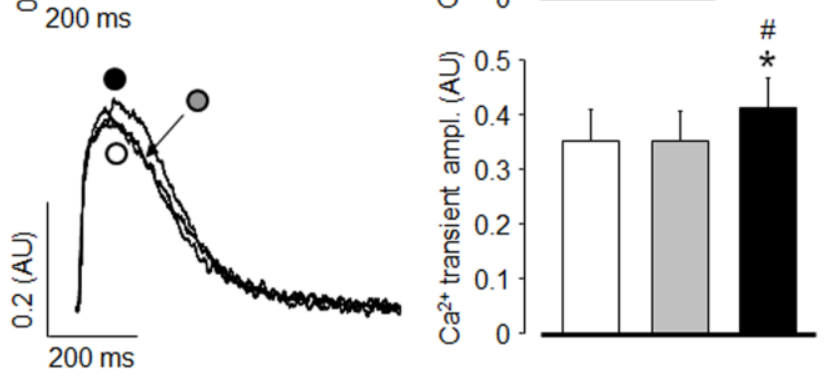

C

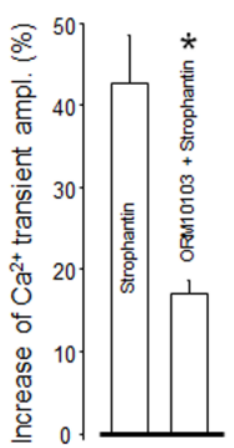

D

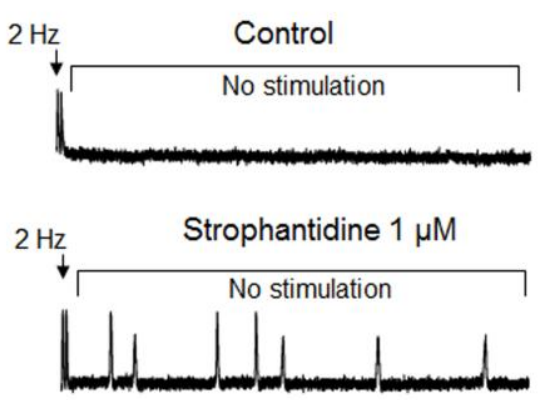

ORM-10103 $10 \mu \mathrm{M}+$ Strophantidine $1 \mu \mathrm{M}$
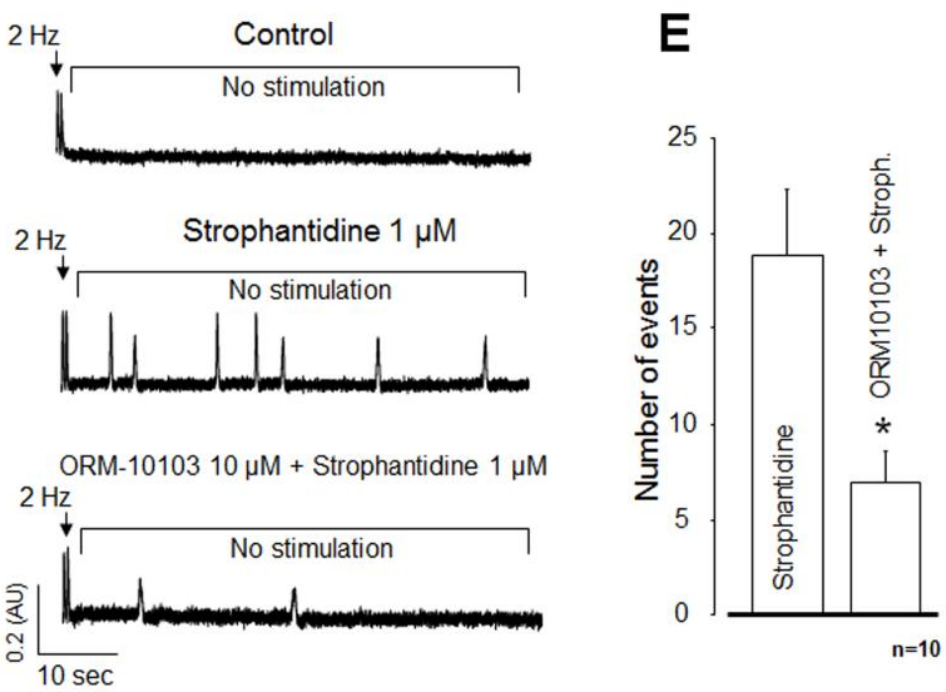

Fig.7.: Antiarrhythmic efficacy of ORM-10103. Inhibition of the $\mathrm{Na}^{+} / \mathrm{K}^{+}$pump with $1 \mu \mathrm{M}$ strophantidine resulted in significantly enhanced $\left[\mathrm{Ca}^{2+}\right]_{i}$ transient $(A)$. This enhancement could be significantly eliminated if the cells were pretreated with $10 \mu M$ ORM-10103 (B). In the presence of strophantidine, $2 \mathrm{~Hz}$ electrical stimulation caused spontaneous diastolic $\mathrm{Ca}^{2+}$ releases, which were largely diminished by $10 \mu M$ ORM-10103 (D). In the case of panels $(C)$ and $(E)$, asterisks indicate significant differences from the strophantidine treated group.

This $1 \mathrm{~Hz}$ period was than followed by the period of $2 \mathrm{~Hz}$ stimulation and a third period with stopped stimulation. Since during the $2 \mathrm{~Hz}$ period a substantial number of large 
diastolic releases could be observed, it seems feasible that under these experimental conditions a substantial $\left[\mathrm{Ca}^{2+}\right]_{i}$ overload was generated. In the absence of strophantidine (control) spontaneous diastolic $\mathrm{Ca}^{2+}$ release was not observed following a short period of rapid $(2 \mathrm{~Hz})$ pacing ( $\mathrm{D}$, upper trace). In contrast, rapid pacing induced multiple arrhythmogenic $\mathrm{Ca}^{2+}$ release events (presumably resulting in DADs) in the presence of 1 $\mu \mathrm{M}$ strophantidine (D, middle trace). Following $10 \mu \mathrm{M}$ ORM10103 pretreatment the same strophantidine challenge was much less effective to evoke spontaneous $\mathrm{Ca}^{2+}$ release (D, lower trace and panel E). In panel B the statistical significance level was verified by repeated measures ANOVA.

\subsection{Effect of selective NCX inhibition on cardiomyocyte viability under ischemic conditions}

The results obtained from the "survival" experiments are summarized in Fig. 8. Representative microscope fields from a pair of experiments performed on untreated and ORM-10103 treated cardiomyocytes are shown in panels (A) and (B), respectively. Instead of using vital dyes, we followed a similarly effective classification, based simply on the shape and visibility of the striation of the cell [30]. This form of classification may also have some benefits since with proper experience one is able to reliably dissect crippled, dying cardiomyocytes from safely surviving cells. For survival analysis regions of interest (ROIs, white circles) containing $\sim 20$ predominantly intact, contracting cardiomyocytes were selected at the beginning of the normoxic period (left panels). Based on their morphological characteristics cells in the ROI were classified into two groups: Class A: elongated cells with intact border and clearly visible striation. Class B: dead cells, or cells on the verge of death with no visible striation and typically in full contracture. At the end of the ischemic period most cardiomyocytes in both ROIs seem to be principally intact (mid panels). At the end of the reperfusion period, however, a substantial number of the cells was in contracture (right panels). This is especially true for the untreated group.

Mean values, determined for both groups in the last minute of the control (normoxic), ischemia and reperfusion periods, are summarized in panel (C). The distribution of cells in the normoxic state was close to identical in both groups, and the majority of these cells were intact (78\% and $81 \%$ in the untreated and ORM-10103 treated groups, respectively). As noted above, ischemia by itself apparently did not influence cell distribution in either group. In contrast, reperfusion had a detrimental effect on the 
untreated group: 71\% (112 out of 156) of the cells intact at the end of ischemia died during reperfusion. Application of $10 \mu \mathrm{M}$ ORM-10103 had a clearly protective effect on cell viability; significantly less, only $47 \%$ (76 out of 161) of the ORM-treated cells died by the end of the reperfusion period.

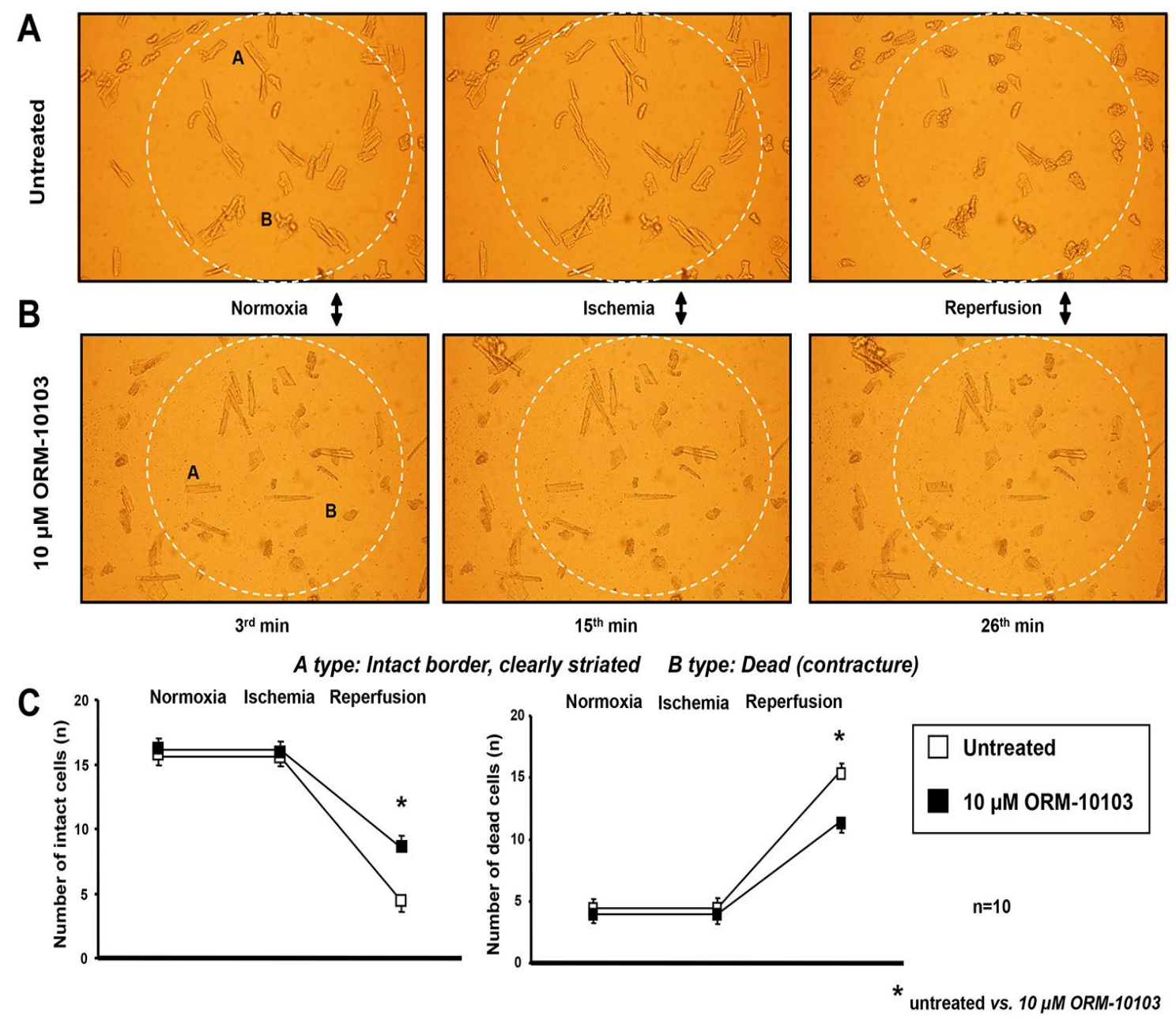

Fig.8.: The effect of $10 \mu M$ ORM-10103 on cardiomyocyte viability. Cardiomyocytes were classified by their shape: Class A intact border and clearly striation, not significantly shortened; Class B dead cells in contracture. Representative microscope fields from 1-1 experiment performed on untreated $(A)$ and ORM-10103 treated (B) cardiomyocytes The mean values are provided on panel $(C)$. The asterisks indicate significant $(P<0.05)$ difference between untreated and ORM-treated values $(n=10)$. 


\subsection{Validation of intracellular ischemia by monitoring NADH levels}

When the cells were not exposed to ischemia (time control group) only a limited, gradual decrease in cellular fluorescence, most likely a consequence of nonspecific changes (bleaching), could be observed (black circles). In contrast, in cells exposed to the ischemia/reperfusion protocol cellular fluorescence increased significantly during the ischemic period (grey circles). When switching perfusion solutions $\sim 30 \mathrm{~s}$ was necessary for the new perfusate to reach the chamber, and about further $\sim 1 \mathrm{~min}$ to mix and decrease the oxygen level in the chamber low enough to induce anaerobic transition. Ischemiainduced NADH shifts were calculated by correcting raw fluorescence values for nonspecific changes. The onset and relative depth of intracellular ischemia were verified by monitoring ischemia induced shifts in inherent fluorescence of dye-unloaded (native) cardiomyocytes and comparing those to nonspecific, time dependent fluorescence shifts developed in nonischemic cells. In order to estimate the depth of intracellular ischemia $\mathrm{NaCN}$ - often used to induce close to maximal short term reduction in $\mathrm{NAD}^{+}$- was applied immediately following the reperfusion period. The results of the NADH fluorescence measurements are shown in (Fig.9).

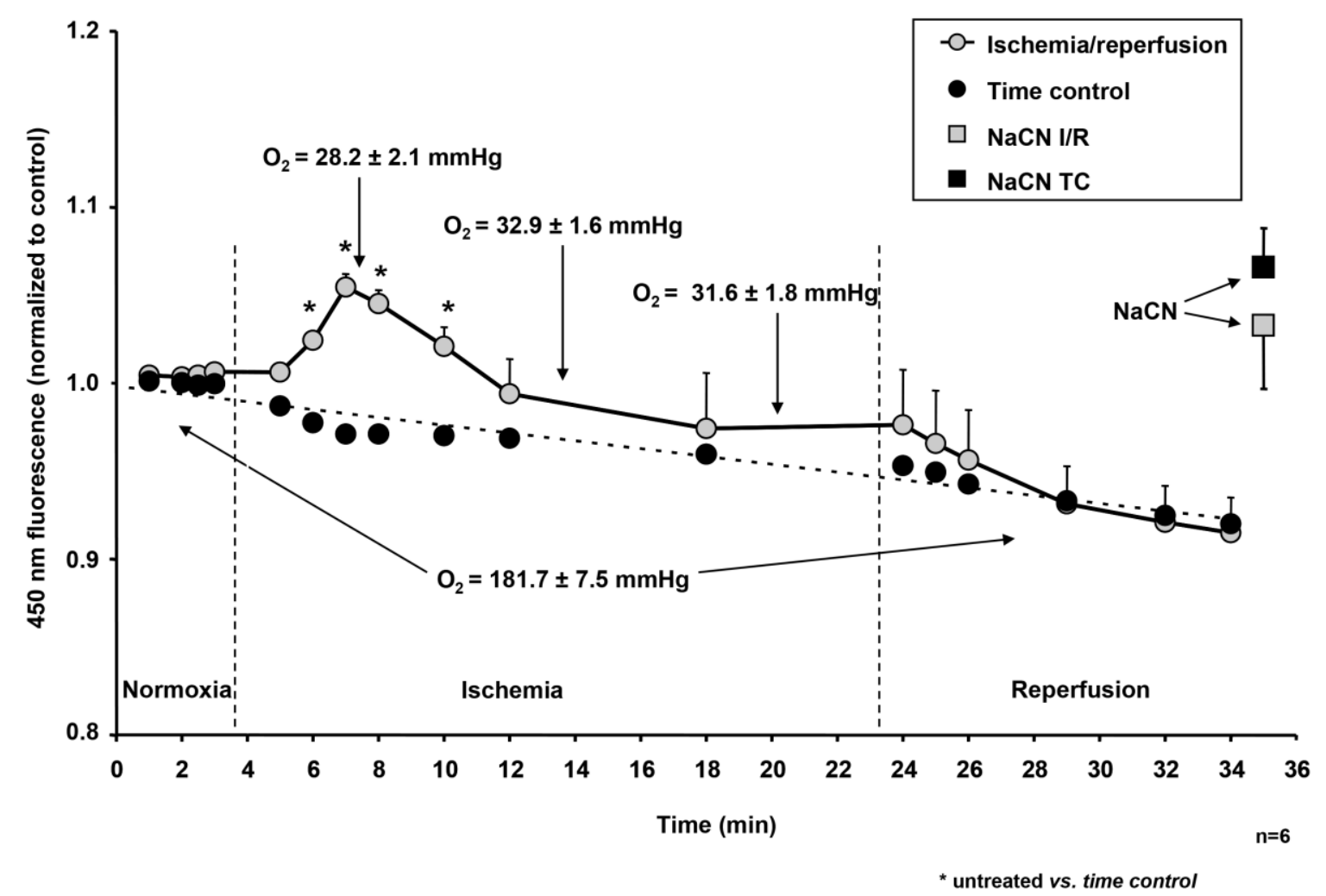

Fig.9.: Effect of simulated ischemia/reperfusion on NADH levels in isolated cardiomyocytes. NADH was excited at $360 \mathrm{~nm}$, native cellular fluorescence has been 
recorded at $450 \mathrm{~nm}$ in untreated, unloaded cardiomyocytes (grey circles). Nonspecific shifts in fluorescence, caused by NADH bleaching, were estimated from normoxic time control measurements (black circles). At the end of both protocols $10 \mathrm{mM}$ sodium-cyanate $(\mathrm{NaCN})$ was applied to induce maximal $N A D H$ reduction (squares). $I / R=i s c h e m i a / r e p e r f u s i o n, \quad T C=$ time control. Asterisks indicate significant $(P<0.05)$ difference between individual ischemic and time control values $(n=6)$.

In the early phase of ischemia a steep increase in [NADH] could be observed ( $8.4 \pm$ $0.4 \% ; \mathrm{n}=6$ ). During the ischemic cycle the level of the corrected fluorescence increase was varying, most probably reflecting the minor variations in oxygen levels inside the chamber. During reperfusion [NADH] gradually returned to control level, even a minimal, insignificant undershoot could be observed. Compared to simulated ischemia, the application of cyanate induced significantly larger $\mathrm{NAD}^{+}$reduction (ischemic and time control cells: $12.2 \pm 2.8 \%$ and $15.1 \pm 1.9 \%$, respectively, $\mathrm{n}=4)$. While the $\mathrm{pO}_{2}$ level in the chamber was sufficiently high during normoxia $(181.7 \pm 7.5 \mathrm{mmHg}, \mathrm{n}=25)$ under ischemic perfusion it was always lower than $40 \mathrm{mmHg}(32.9 \pm 1.6 \mathrm{mmHg}, \mathrm{n}=25)$.

\subsection{The effect of selective NCX inhibition on the $\left[\mathrm{Ca}^{2+}\right]_{\mathrm{i}}$ transient during simulated ischemia}

During simulated ischemia in both strophantidine untreated (Fig.10A) and treated (Fig.11A) cells significant changes in the magnitude and kinetics of the CaT could be observed. Ischemia/reperfusion induced changes in characteristic parameters of the CaT in strophantidine-untreated cells are summarized in the panels A-E of Figure 10. Significant changes in the amplitude of the CaT in untreated compared to time control cells could only be observed during the early phase of ischemia (0.836 \pm 0.03 vs. $0.979 \pm 0.02 ; n=14)(B)$. In contrast, $10 \mu \mathrm{M}$ ORM-10103 caused a steady, gradual decrease in the amplitude of the $\mathrm{CaT}(0.76 \pm 0.06$ vs. $0.38 \pm 0.05 ; \mathrm{n}=14)$, which became significant (compared to ORM10103 untreated cells) during reperfusion. In the slope of the transient (C) ischemia induced a gradual, significant decrease in untreated cardiomyocytes compared to time control $(0.55 \pm 0.07$ vs. $0.54 \pm 0.05 \mathrm{n}=14)$ and ORM treatment had no apparent effect on this decrease. 

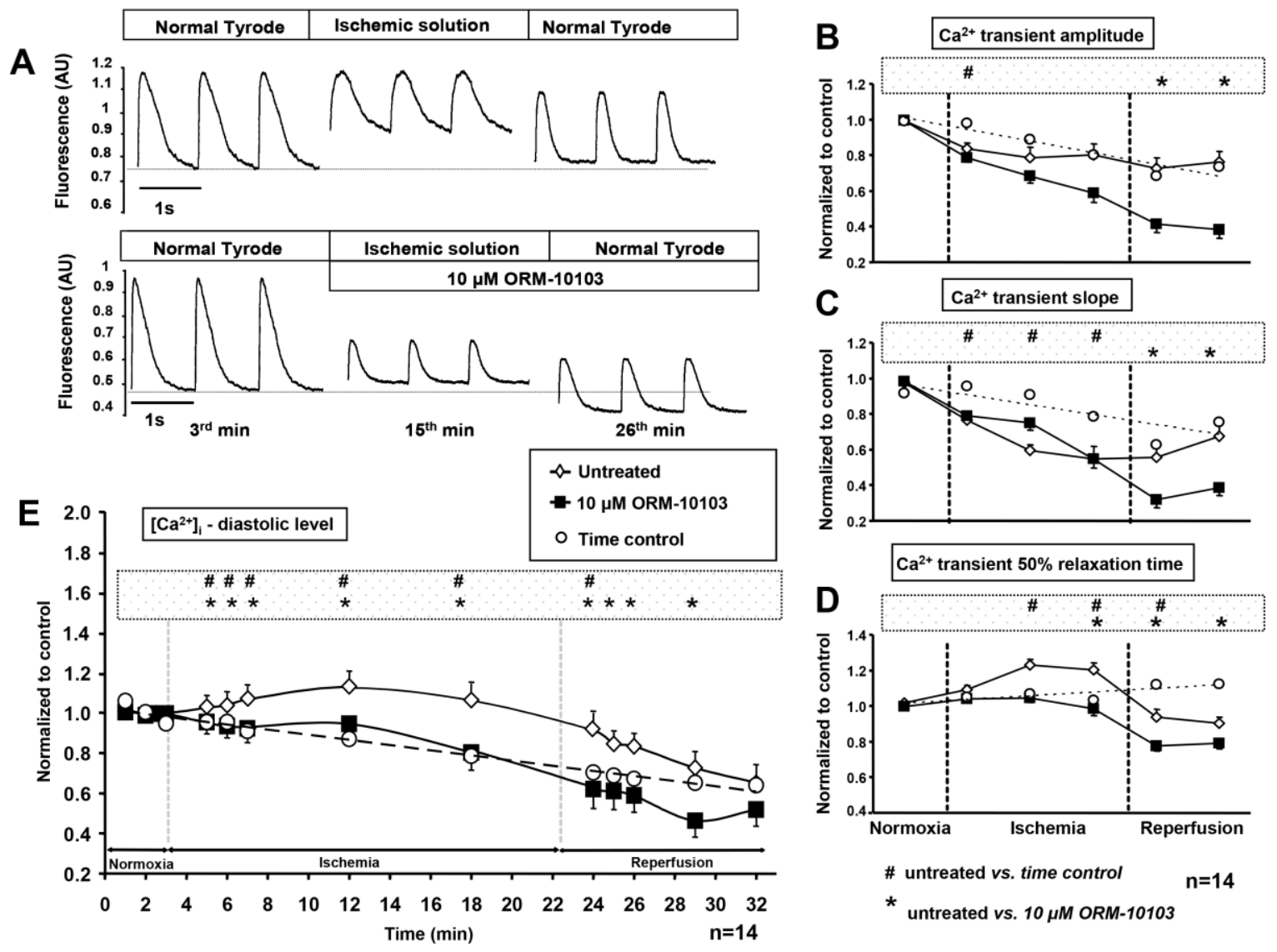

Fig.10.: Changes in major CaT parameters during simulated ischemia/reperfusion and the effect of $10 \mu M$ ORM-10103 treatment on these parameters in strophantidineuntreated cardiomyocytes. (A) Representative raw recordings of CaT in cardiomyocites. (B-E) Ischemia/reperfusion induced shifts in major CaT variables and the effect of $10 \mu M$ ORM-10103 on the (B) magnitude, (C) slope and $(D)$ half relaxation time of the transients. Parameter values were obtained in the $3^{\text {rd }}$ min (control), $6^{\text {th }}, 10$ th, and $15^{\text {th }}$ min (early, mid and late phase of ischemia), and $26^{\text {th }}$ and $30^{\text {th }}$ min (early and late phase of reperfusion) of the recordings. The changes in $\left[\mathrm{Ca}^{2+}\right]_{i D}$ levels are shown in $(E)$ panel. Fluorescence data were analyzed using Students t test for paired or unpaired data, as relevant. Hash marks and asterisks indicate significant $(P<0.05)$ difference between individual time control vs. untreated and untreated vs. ORM-treated values, respectively.

On the other hand, during reperfusion the slope in the two groups changed in opposite direction - recovered in untreated, further decreased in treated cells, the differences between the two groups became significant $(0.67 \pm 0.09$ vs. $0.39 \pm 0.04 ; n=14)$. In untreated cells ischemia also caused a significant increase in the half relaxation time $\left(\mathrm{RT}_{50}\right)$ of the CaT, compared to time control (D). In these cells $\mathrm{RT}_{50}$ recovered during reperfusion, typically with a moderate undershoot compared to time control. In contrast, treatment with ORM-10103 significantly decreased $\mathrm{RT}_{50}(0.90 \pm 0.03$ vs. $0.79 \pm 0.03$; $\mathrm{n}=14$ ) during late ischemia and reperfusion, compared to untreated cells. The largest modulatory effect of ORM-10103 treatment could be observed in $\left[\mathrm{Ca}^{2+}\right]_{\mathrm{iD}}(\mathrm{E})$. As 
expected, ischemia induced a substantial rise in $\left[\mathrm{Ca}^{2+}\right]_{\mathrm{iD}}$, which became significant by the $2^{\text {nd }}$ min of ischemia. Upon reperfusion $\left[\mathrm{Ca}^{2+}\right]_{\mathrm{iD}}$ slowly normalized, however, during its early phase $(\sim 6 \mathrm{~min})$ it was still significantly higher than in time control cells $(1.04 \pm 0.03$ vs. $0.92 \pm 0.02 ; \mathrm{n}=14)$. Pretreatment of the cardiomyocytes with $10 \mu \mathrm{M}$ ORM-10103 completely eliminated the rise in $\left[\mathrm{Ca}^{2+}\right]_{\mathrm{iD}}$ and by the end of the ischemic period it even decreased below time control $(0.73 \pm 0.08$ vs. $0.64 \pm 0.06 ; n=14)$. During reperfusion $\left[\mathrm{Ca}^{2+}\right]_{\mathrm{iD}}$ in these cells was permanently below control.

Ischemia/reperfusion induced changes in characteristic parameters of the $\mathrm{CaT}$ in strophantidine treated cells are summarized in panels A-E of Fig.11. In these cells no significant changes in the amplitude of the CaT could be observed during ischemia or reperfusion (B). Compared to time control, the slope of the CaT gradually, but significantly decreased during both ischemia and reperfusion (C). ORM-10103 failed to influence the ischemia induced fall in the slope of the CaT, but significantly limited its further decrease during reperfusion $(0.55 \pm 0.1$ vs. $0.21 \pm 0.02 ; n=6)$. In ORM-10103 untreated cells $\mathrm{RT}_{50}$ was close to the time control during both ischemia and reperfusion (D). In contrast, the application of $10 \mu \mathrm{M}$ ORM-10103 induced a significant decrease in this parameter during reperfusion $(1.17 \pm 0.11$ vs. $0.81 \pm 0.06 ; \mathrm{n}=6)$. The already significant ischemia-induced elevation in $\left[\mathrm{Ca}^{2+}\right]_{\mathrm{iD}}$, observed in the untreated myocytes, was further significantly augmented in strophantidine treated cells (E) and this marked increase was apparently maintained during the entire period of reperfusion. Application of $10 \mu \mathrm{M}$ ORM-10103 completely eliminated the huge ischemia induced elevation in $\left[\mathrm{Ca}^{2+}\right]_{\mathrm{iD}}$; indeed, diastolic $\left[\mathrm{Ca}^{2+}\right]_{\mathrm{i}}$ levels in these cells did not differ significantly from levels measured in normoxic cardiomyocytes $(0.71 \pm 0.06$ vs. $0.65 \pm 0.06 ; \mathrm{n}=6)$. 

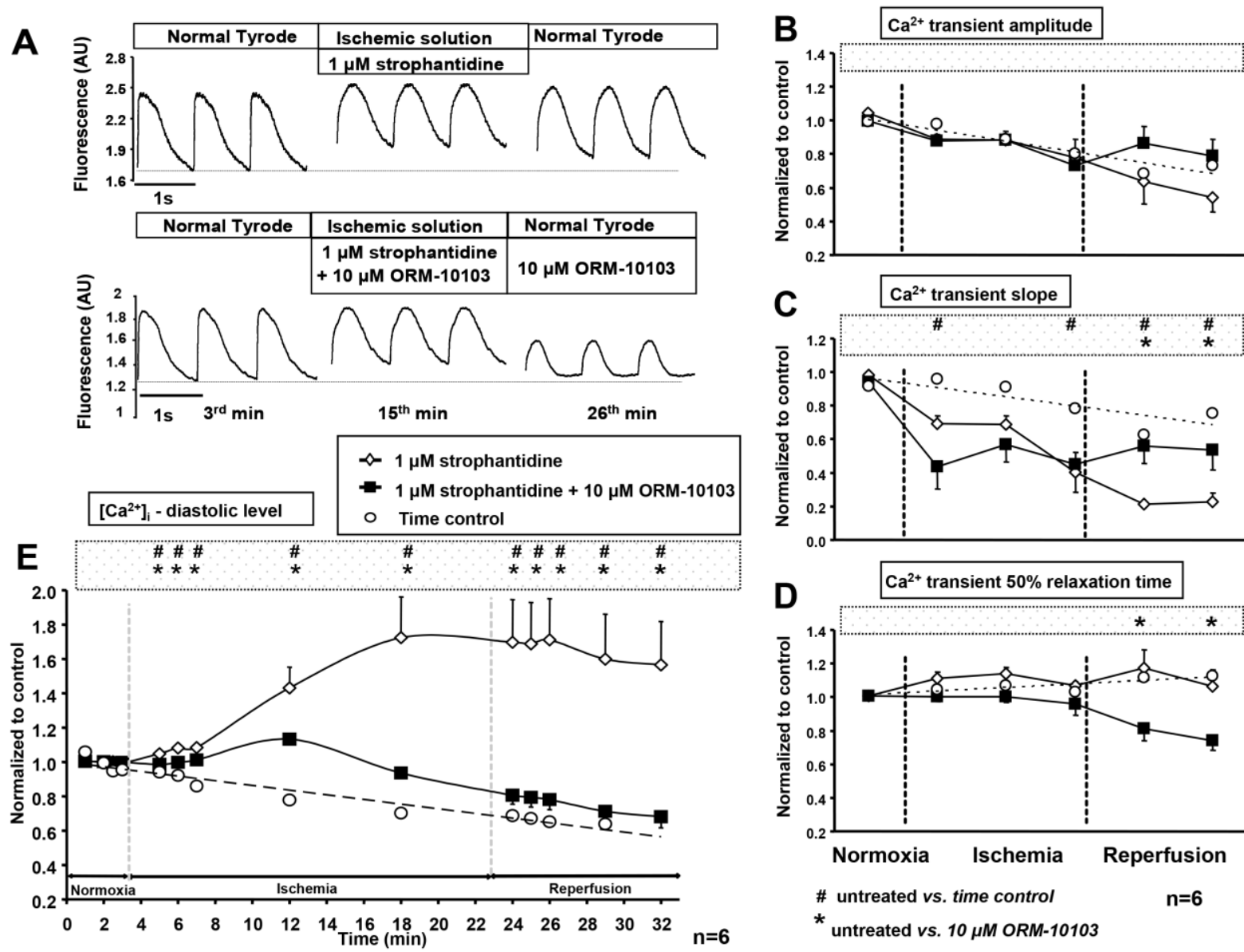

Fig.11.: Changes in major CaT parameters during simulated ischemia/reperfusion and the effect of $10 \mu \mathrm{M}$ ORM-10103 in strophantidine-treated cardiomyocytes. Representative raw recordings of CaT from untreated (upper traces) and ORM-treated (lower traces) cells prior to, during and following simulated ischemia. (B-E) Ischemia/reperfusion induced shifts in major CaT variables and the effect of $10 \mu M$ ORM-10103 on the (B) magnitude, $(C)$ slope and $(D)$ half relaxation time of the transients, and $(E)\left[\mathrm{Ca}^{2+}\right]_{\mathrm{iD}}$ levels. Data were analyzed using Students $t$ test for paired or unpaired data, as relevant revealed that the difference between untreated and ORM-treated curves in both experimental settings is significant $(P<0.05)$. The asterisks indicate significant $(P<0.05)$ difference between individual untreated and ORM-treated values.

The beneficial effect of ORM-10103 treatment during reperfusion became even more evident by comparing short term variabilities of the CaT amplitudes. Variabilities calculated from all four experimental groups for the normoxic, ischemic and reperfusion periods are summarized in Fig.12. Representative Poincare plots, obtained in untreated, ORM-10103 treated, strophantidine treated and strophantidine + ORM-10103 treated cells, are shown in panels A, B, C and D, respectively. Mean data from untreated and ORM10103 treated cells are provided in panel (E). As one can conclude from these diagrams, in untreated cells no apparent ischemia/reperfusion induced changes in CaT variabilities 
could be observed, while ORM-10103 treatment caused a small, rather insignificant decrease in both cases $(0,011 \pm 0.002$ vs. $0.010 \pm 0.001$ and $0,012 \pm 0.003$ vs. $0.010 \pm$ $0.001 ; \mathrm{n}=6$, during ischemia and reperfusion, respectively). In contrast, as shown in panel (F), during ischemia strophantidine significantly enhanced the short term variability $(0.113$ \pm 0.037 vs. $0.037 \pm 0.016 ; \mathrm{n}=6$ ) which was even further augmented during reperfusion $(0,272, \pm 0,055 . v s .0,018 \pm 0,009 ; \mathrm{n}=6)$. This large elevation was, again, fully eliminated by the application of $10 \mu \mathrm{M}$ ORM-10103.
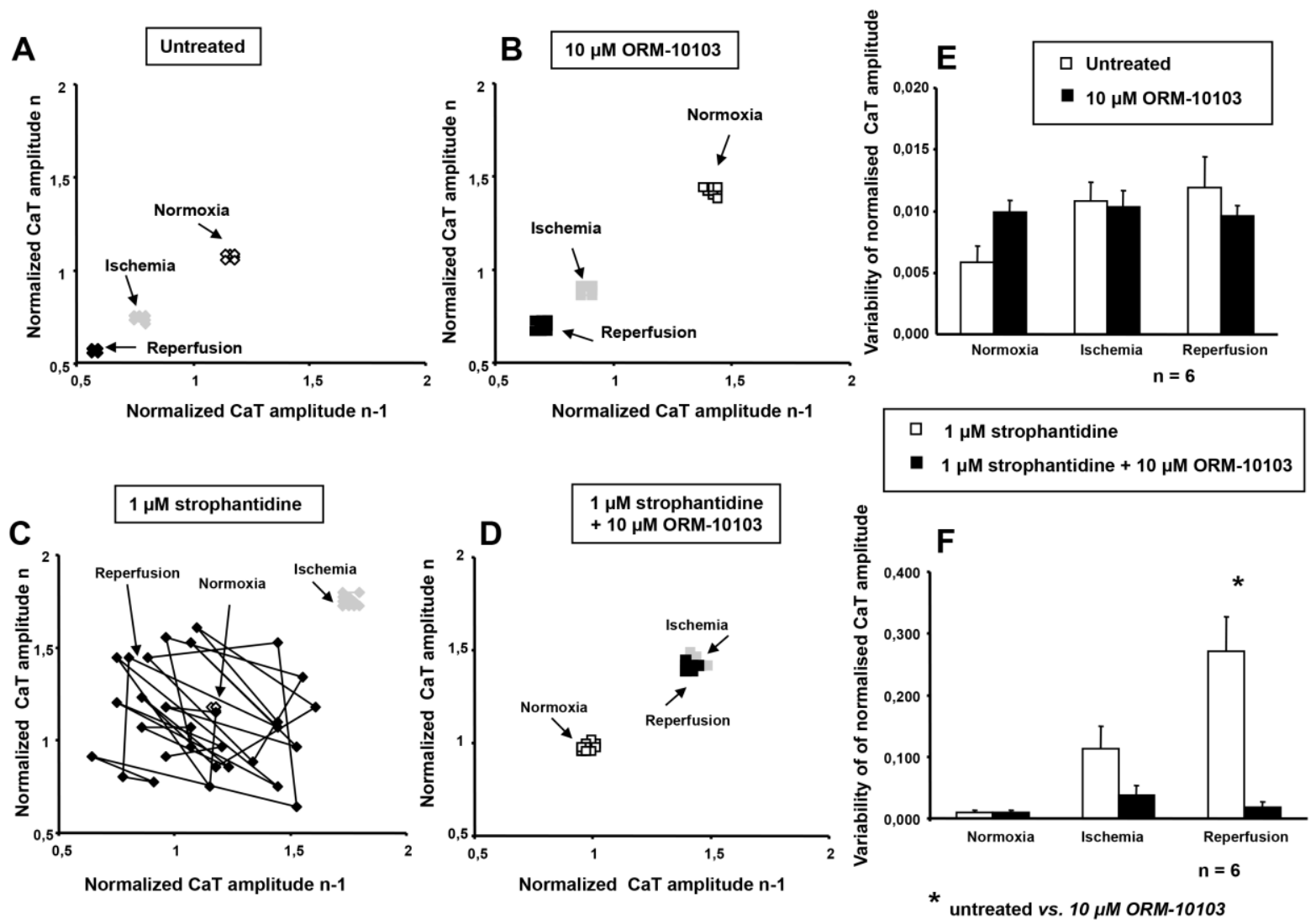

Fig.12.: The effect of $10 \mu M$ ORM-10103 on the variability of the $\left[\mathrm{Ca}^{2+}\right]_{i}$ transient amplitude. Representative examples are presented in panels (A-D). Variabilities for strophantidine-untreated and treated cardiomyocytes are summarized in panels $(E)$ and $(F)$, respectively. While no significant differences could be found in the absence of strophantidin, in the treated group ischemia and reperfusion caused large, significant increase in variability, which was fully prevented by ORM-10103 treatment. The asterisk indicates significant $(P<0.05)$ difference between individual untreated and ORM-treated values

\subsection{Effect of selective NCX inhibition on AP parameters}

Representative AP waveforms are shown in Fig.13. During normoxia $10 \mu \mathrm{M}$ ORM10103 evoked moderate APD shortening without substantially modulating either its amplitude or the resting membrane potential (A). During simulated ischemia, however, 
significant changes in the shape and kinetics of the APs developed and the resting membrane potential was depolarized (middle trace in panel B). Both parameters were apparently normalized during reperfusion (right trace in panel B). The AP shortening effect of $10 \mu \mathrm{M}$ ORM-10103 observed in normoxic cells was even more evident during both ischemia and reperfusion (panel C); however, no additional ORM-10103 induced shifts in AP could be observed. Indeed, the ORM-treatment failed to substantially reduce the ischemia induced depolarization of the resting membrane potential.

A

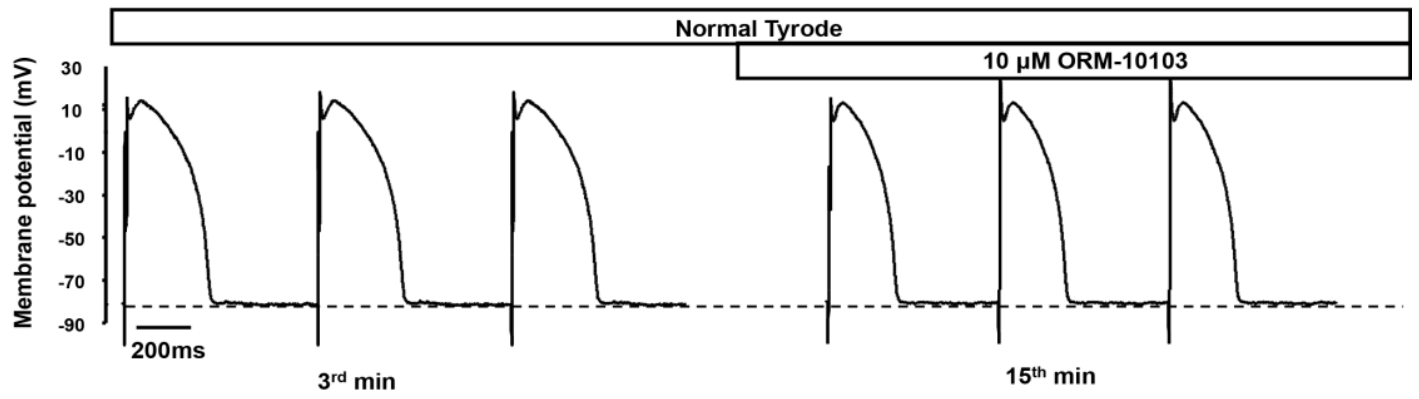

B
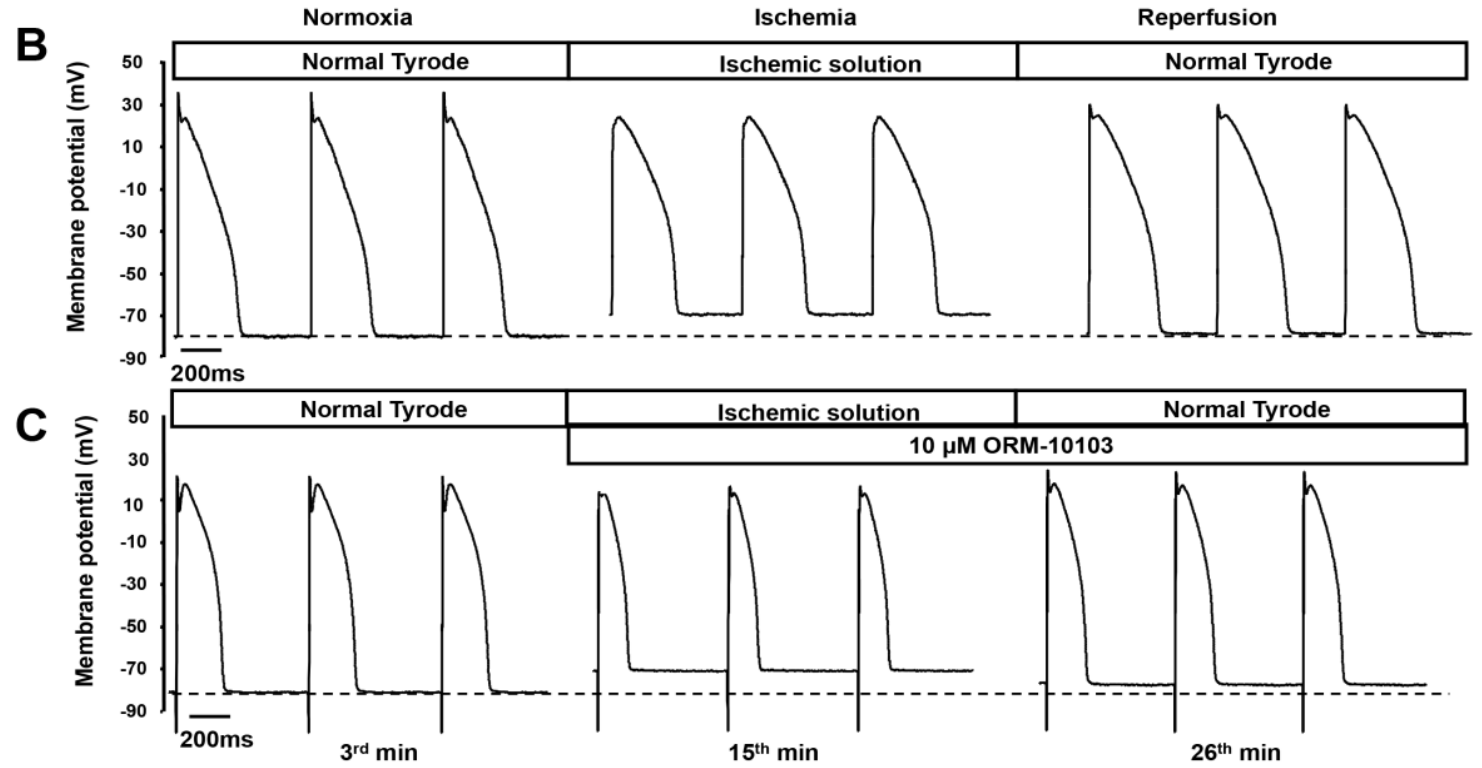

Fig.13.: Representative traces from the action potential measurements. AP measurements were performed in native (dye-unloaded) cells. The effect of $10 \mu M$ ORM-10103 on normoxic cardiomyocytes (A). The effect of the simulated ischemia/reperfusion protocol on action potentials recorded from ORM-10103-untreated (B) and treated (C) cardiomyocytes, respectively.

Ischemia/reperfusion induced alterations in the characteristic parameters of the AP in untreated and ORM-10103 treated cardiomyocytes are summarized in Fig.14. Compared to normoxic cells, ischemia induced a significant reduction in the amplitude, a substantial, but not significant decrease in the plateau level of the AP (A, B), and the resting membrane potential became significantly depolarized $(\mathrm{C})$. These parameters were practically restored 
during reperfusion. ORM-10103 had no apparent effect on the magnitude of the ischemia induced shifts, neither on the recovery of these variables.
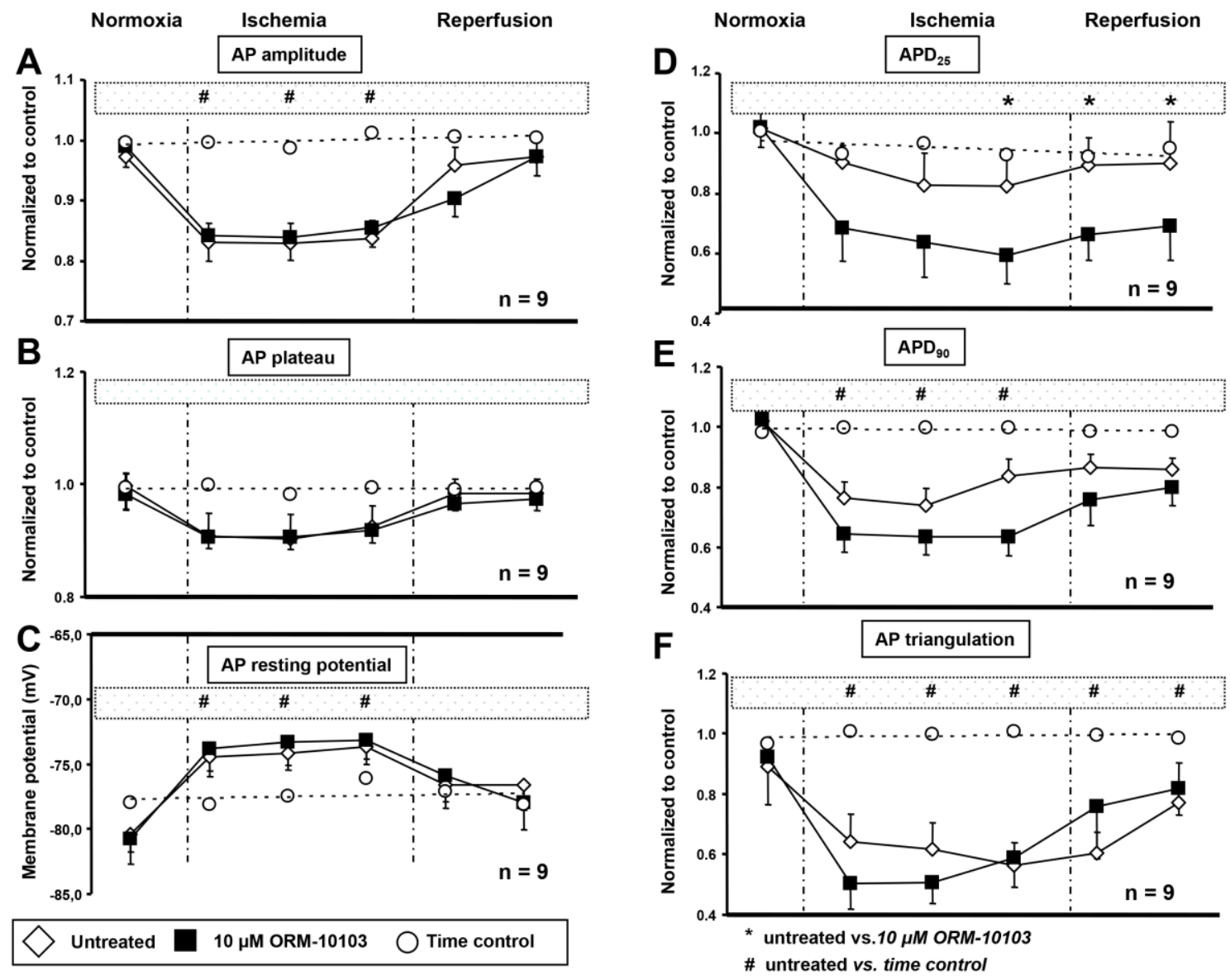

Fig.14.: Changes in major AP parameters during simulated ischemia/reperfusion

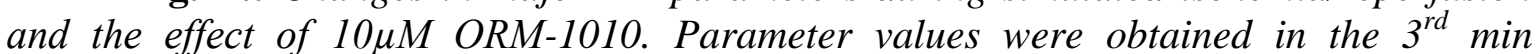
(control), $6^{\text {th }}, 10^{\text {th }}$ and $15^{\text {th }}$ min (early, mid and late phase of ischemia), and $26^{\text {th }}$ and $30^{\text {th }}$ min (early and late phase of reperfusion) of the measurements: (A) amplitude; (B) plateau level; $(C)$ resting membrane potential; $(D) A P D_{25} ;(E) A P D_{90} ;$ and $(F)$ triangulation. All data analyzed using Students $t$ test for paired or unpaired data, as relevant. Hash marks and asterisks indicate significant $(P<0.05)$ difference between individual time control vs. untreated and untreated vs. ORM-treated values, respectively.

In order to characterize major changes in AP kinetics $\mathrm{APD}_{25}$ (D) and $\mathrm{APD}_{90}(\mathrm{E})$ were determined and from these variables AP triangulation was calculated $(\mathrm{F})$. Ischemia induced a moderate decrease in $\mathrm{APD}_{25}$ which was normalized during reperfusion. Compared to the untreated cells substantially larger decrease in $\mathrm{APD}_{25}$ could be observed in ORM-10103 treated cardiomyocytes, became significant in the late phase of ischemia and did not recover during reperfusion $(0.90 \pm 0.09$ vs. $0.66 \pm 0.09 ; n=9)$. Qualitatively similar, but augmented ischemia induced shortening could be observed in $\mathrm{APD}_{90}$, however, the differences between the two groups were not significant during either ischemia or 
reperfusion. Compared to the time control cells, ischemia induced a large, significant decrease in AP triangulation in both groups, but again, the differences between the untreated and ORM-10103 treated groups were not significant $(0.61 \pm 0.07$ vs. $0.76 \pm 0.17$; $\mathrm{n}=9)$.

Results of these calculations of short term variabilities in $\mathrm{APD}_{90}$ and $\mathrm{APD}_{25}$ are summarized in Fig.15. Representative Poincare plots taken from untreated and ORM10103 treated cardiomyocytes are presented in panels (A-D). The average values obtained in the $\mathrm{APD}_{90}$ and $\mathrm{APD}_{25}$ groups are shown in panels $(\mathrm{E})$ and $(\mathrm{F})$, respectively. Under normoxic conditions APD variabilities were similar in both groups. Ischemia induced moderate, but insignificant decrease in $\mathrm{APD}_{90}$ variabilities in the untreated group, while there was no apparent change in the ORM-10103 treated group. In contrast, $\mathrm{APD}_{25}$ variabilities failed to change in the control group, but showed a tendency to decrease following ORM-10103 treatment. During reperfusion the only significant change was an elevation in $\mathrm{APD}_{90}$ variabilities determined in the untreated group. ORM-10103 treatment eliminated this increase $(5.37 \pm 0.96$ vs. $3.47 \pm 0.69 \mathrm{~ms} ; \mathrm{n}=9)$.
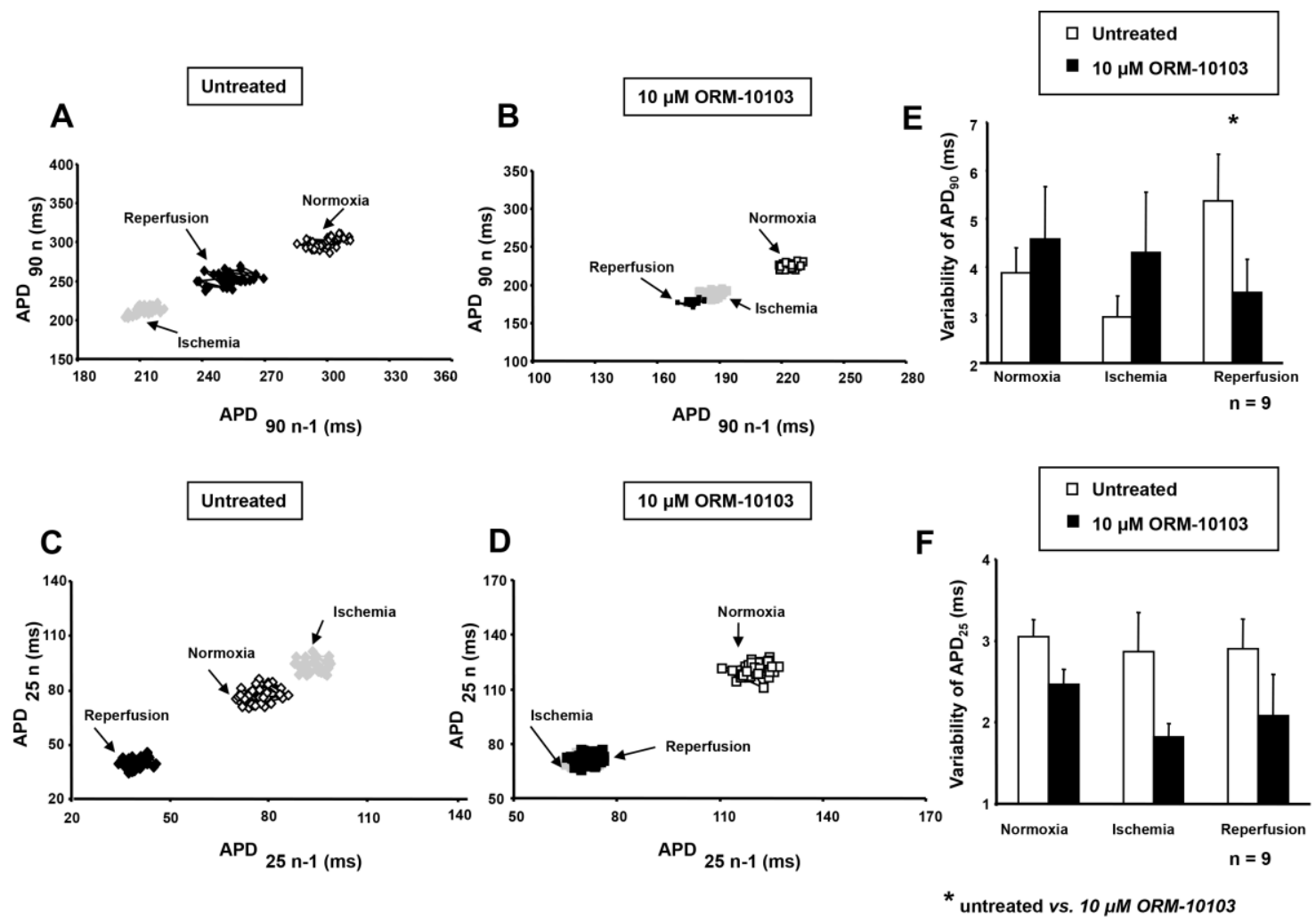

Fig.15.: The effect of $10 \mu M$ ORM-10103 on $A P D_{90}$ and $A P D_{25}$ variabilities. Representative examples for variabilities in $A P D_{90}$ and $A P D_{25}$ in untreated and ORMtreated groups are presented in panels $(A-B)$ and $(C-D)$, respectively. Summarized data are shown in panels $(E)$ and $(F)$. The asterisks indicate significant $(P<0.05)$ difference between untreated and ORM-treated values 


\section{Discussion}

The possible antiarrhythmic effect of NCX inhibition can be attributed to its important role to prevent the $\mathrm{I}_{\mathrm{NaL}}$-mediated and ischemia/reperfusion induced $\left[\mathrm{Ca}^{2+}\right]_{\mathrm{i}}$ overload. In both pathological conditions partial NCX inhibition may restore the balance in intracellular $\mathrm{Ca}^{2+}$ handling, resulting in decreased propensity for arrhythmias. Since the cardiac $\mathrm{Na}^{+} / \mathrm{Ca}^{2+}$ exchanger has a crucial role in maintaining $\left[\mathrm{Ca}^{2+}\right]_{\mathrm{i}}$ homeostasis, any abnormal shift in its transport rate may significantly contribute to alteration of the contractile function and electric activity of the heart. In our experiments the effects of selective $\mathrm{I}_{\mathrm{NCX}}$ inhibition on $\left[\mathrm{Ca}^{2+}\right]_{\mathrm{i}}$ homeostasis have been evaluated under arrhythmogenic conditions.

Enhanced reverse mode activity may induce $\left[\mathrm{Ca}^{2+}\right]_{\mathrm{i}}$ overload, while its enhanced forward mode transport leads to gradual $\left[\mathrm{Ca}^{2+}\right]_{\mathrm{i}}$ loss. [36-38]. While a number of previous studies provided important information on the consequences of NCX inhibition in healthy and diseased hearts, interpretation of these results was hampered by the fact, that the applied inhibitors were not selective [29;40]. In this respect, our results allow new insight into the physiological and pathophysiological role of NCX, since we used ORM-10103, a new NCX inhibitor with excellent specificity and selectivity [34] during $\mathrm{Na}^{+}$induced $\left[\mathrm{Ca}^{2+}\right]_{\mathrm{i}}$ load and during simulated ischemia/reperfusion in isolated canine ventricular cardiomyocytes [40]. The most important effects of ORM-10103 were studied on CaT and AP, parameters relevant in terms of arrhythmia development. Application of $10 \mu \mathrm{M}$ ORM10103 had a clearly protective effect on cell viability because numerous of ORM-untreated cells died by the end of the reperfusion period. Moreover ischemia induced a substantial rise in $\left[\mathrm{Ca}^{2+}\right]_{\mathrm{iD}}$, and the application of $10 \mu \mathrm{M}$ ORM-10103 completely eliminated this rise in $\left[\mathrm{Ca}^{2+}\right]_{\mathrm{iD}}$. Furthermore, during ischemia/reperfusion the short term variability of the CaT and AP - a well known arrhythmia marker - became significantly enhanced in strophantidine treated cells, and this large increase was fully eliminated by the application of $10 \mu \mathrm{M}$ ORM-10103.

\subsection{Selective NCX inhibition does not influence CaT kinetics under physiological conditions}

In a predominant number of cardiomyocytes applications of NCX inhibition by $10 \mu \mathrm{M}$ ORM-10103 during physiological conditions did not cause apparent changes in the magnitude, shape and decay kinetics of the CaT. Under physiological conditions we did 
not find apparent effect on CaT parameters in the present of NCX inhibition by ORM10103 (Fig.5). These results are in line with our previous work [41-42]. The background of this effect is complex. As we can find it in the literature, markedly different results were obtained in small species, where NCX inhibition increased the magnitude of $\left[\mathrm{Ca}^{2+}\right]_{\mathrm{i}}$ transients. This may be due to the short action potential duration in contrast to dogs and humans, where the action potential duration is longer. NCX spends relatively longer time in its forward mode during the AP in small species (rat) than in larger animals (dog), which may lead to increased $\left[\mathrm{Ca}^{2+}\right]_{\mathrm{i}}$ transient when NCX is blocked [43-44]. This is the possible reason why in our canine myocytes ORM-10103 induced changes in CaT was failed.

\subsection{The effect of selective $\mathrm{NCX}$ inhibition against $\mathrm{I}_{\mathrm{NaL}}$ induced $\left[\mathrm{Ca}^{2+}\right]_{i}$ rise on the $\left[\mathrm{Ca}^{2+}\right]_{i}$ parameters}

The selective NCX inhibitor ORM-10103 effectively reduced the increased $\left[\mathrm{Ca}^{2+}\right]_{\mathrm{i}}$ and prevented the $\mathrm{I}_{\mathrm{NaL}}$-mediated rise in $\left[\mathrm{Ca}^{2+}\right]_{\mathrm{i}}$. The ATX-II induced $\mathrm{I}_{\mathrm{Na}}$ increase leads to net gain in $\left[\mathrm{Na}^{+}\right]_{\mathrm{i}}$, shifting subsequently the reversal potential of the NCX in ventricular cardiomyocytes. If we added ATX-II before the NCX inhibitor, the increased intracellular $\mathrm{Na}^{+}$activated the reverse NCX, leading to raised CaTs. Application of an $\mathrm{I}_{\mathrm{NCX}}$ inhibitor reduced the enhanced reverse $\mathrm{I}_{\mathrm{NCX}}$ and limited further $\mathrm{Ca}^{2+}$ influx. The $\mathrm{I}_{\mathrm{NaL}}$ activation caused increase in the $\left[\mathrm{Ca}^{2+}\right]_{\mathrm{i}}$, which was prevented following the selective NCX blockade. This secondary increase in ${ }_{\text {rev }} \mathrm{I}_{\mathrm{NCX}}$ was fully abolished by pretreatment with $10 \mu \mathrm{M}$ ORM10103. This clearly indicates the pathogenetic role of reverse NCX in the $\mathrm{I}_{\mathrm{NaL}}$-induced $\left[\mathrm{Ca}^{2+}\right]_{i}$ overload and arrhythmia. Thus, these data support important role in cardiac arrhythmogenesis of the $\mathrm{I}_{\mathrm{NaL}}$ activation and may suggest the beneficial antiarrhythmic effects of NCX inhibition (Fig.6-7).

According to our previous results we would like to examine, whether the NCX blocker ORM-10103 is able to prevent $\left[\mathrm{Ca}^{2+}\right]_{\mathrm{i}}$ overload under conditions of simulated ischemia/reperfusion injury.

\subsection{Selective NCX inhibition increased the cell survival during ischemia/reperfusion}

A most direct way to test the efficacy of the selective NCX blockade in protecting cardiomyocytes against ischemia/reperfusion injuries is to compare cell survival between untreated and treated groups (Fig. 1). The results of these experiments are straightforward and seem to support the hypothesis that partial, selective NCX inhibition by ORM-10103 
may effectively protect the cardiomyocytes from severe ischemia/reperfusion induced injuries. This protection is most probably a direct consequence of the NCX inhibitory effect on the buildup of ischemia-induced $\left[\mathrm{Ca}^{2+}\right]_{\mathrm{i}}$ overload leading to contracture and elevated $\left[\mathrm{Ca}^{2+}\right]_{\mathrm{iD}}$, which may severely compromise mitochondrial function [45]. A further contribution of ORM-10103 to cardiomyocyte survival may be its significant stabilizing effect on the CaT and APD by inhibiting the ischemic increase in their variabilities [37].

\subsection{Measurement of the severity of intracellular ischemia}

Sustained ischemia is characterized by modified and deprived energy metabolism. Oxidative metabolism is blocked, while glycolysis is enhanced [46]. As a consequence of the anaerobic shift, the mitochondrial $\mathrm{NAD}^{+}$content is reduced. Increased NADH level is reflected by the increased native fluorescence of the cells at $450 \mathrm{~nm}$. Close to maximal NADH levels can be reached by the application of cyanate $\left(\mathrm{CN}^{-}\right)$. The relative magnitude of the fluorescence-increase induced by simulated ischemia was compared to the rise achieved by the application of $10 \mathrm{mM} \mathrm{NaCN}$. This relative increase was used to characterize the level of ischemia.

The fluorescence increase observed in our experiments during the simulated ischemia protocol was substantially less than the level reached in the presence of cyanate (Fig. 9). Consequently, our protocol could induce only partial ischemia, i.e. the oxidative metabolism was severely compromised [21] but not fully abolished. This is not surprising, since the oxygen level in the imaging chamber was rather low, but definitely not zeros $(32.9 \pm 1.6 \mathrm{mmHg})$. Therefore, the simple simulated ischemia protocol is probably more suitable to model the lateral, low-flow zone of the infarcted area than the central now-flow region. Another important observation was that fluorescence was gradually decreasing after reaching an early maximum. This decrease was probably not a consequence of NADH bleaching, since the rate of bleaching can satisfactorily be estimated from the time control measurements. Indeed, it may arise from two sources. First, $\mathrm{pO}_{2}$ in the chamber was probably close to the critical $\mathrm{pO}_{2}$ value for isolated, active cardiomyocytes and even a small shift in chamber $\mathrm{pO}_{2}$ may induce substantially larger shift in the NADH concentration. Possible reason for the fluorescence decay observed during ischemia is that it may also reflect changes in substrate availability. In the moment we have no data to settle this issue - both explanations may be possible - they may act even simultaneously. 
Both $\left[\mathrm{Ca}^{2+}\right]_{i}$ and $\left[\mathrm{Na}^{+}\right]_{\mathrm{i}}$ become gradually elevated during ischemia/reperfusion [47]. The excessive rise in $\left[\mathrm{Na}^{+}\right]_{\mathrm{i}}$ is a consequence of the simultaneous depression of NKA and activation of NHE. As a consequence of the increased $\left[\mathrm{Na}^{+}\right]_{i}, \mathrm{NCX}$ is shifted towards its reverse transport mode. This shift is further facilitated by substantial depolarization of the sarcolemma. During reperfusion the already large ischemia-induced elevation of $\left[\mathrm{Ca}^{2+}\right]_{\mathrm{i}}$ is further increased, partially because of the largely augmented $\left[\mathrm{Na}^{+}\right]_{i}$ caused by the full activation of NHE and also due to the facilitating effect of the increased ROS generation [48].When combined, these two effects often result in fast and dramatic further increase in $\left[\mathrm{Ca}^{2+}\right]_{\mathrm{i}}$ leading to extreme overload, reperfusion-induced cellular injury and enhanced arrhythmia propensity. [1].

\subsection{The effect of selective NCX inhibition during simulated ischemia/reperfusion on the $\left[\mathrm{Ca}^{2+}\right]_{i}$ parameters}

According to our results consequences of $\left[\mathrm{Ca}^{2+}\right]_{\mathrm{i}}$ accumulation could be observed in untreated cells (Fig.10A-E). Diastolic $\left[\mathrm{Ca}^{2+}\right]_{i}$ significantly increased (Fig.10A), and since the amplitude of the transient did not decrease simultaneously (Fig.10B), systolic $\left[\mathrm{Ca}^{2+}\right]_{\mathrm{i}}$ was also enhanced (not shown). The kinetic parameters of CaT were also altered. The slope of the transient decreased, while $\mathrm{RT}_{50}$ increased during ischemia (Fig.10C-D), reflecting the relative energy deficit as a consequence of the metabolic transition. The background of this effect may be rather complex: ATP depletion reduces SERCA activity (leading to decreased $\mathrm{Ca}^{2+}$ content of the SR; see the reduced slope and amplitude of the $\mathrm{CaT}$ ), the increased resting membrane potential decreases the drive for the forward, the high $\left[\mathrm{Na}^{+}\right]_{\mathrm{i}}$ increases the drive for reverse $\mathrm{NCX}$ current [1], the latter facilitates $\mathrm{Ca}^{2+}$ influx leading to elevated $\left[\mathrm{Ca}^{2+}\right]_{\mathrm{i}}$ level to be extruded [4;49]. Therefore, we suggest that in this experimental model the $\mathrm{Ca}^{2+}{ }_{i}$ content of the SR is decreased (via reduced SERCA and forward NCX activity), the $\left[\mathrm{Ca}^{2+}\right]_{i}$ level is elevated. Upon reperfusion the amplitude and slope of the $\left[\mathrm{Ca}^{2+}\right]_{\mathrm{i}}$ transient and - although quite slowly - the diastolic $\left[\mathrm{Ca}^{2+}\right]_{\mathrm{i}}$ were restored [40]. In contrast, $\mathrm{RT}_{50}$ was significantly shortened during reperfusion. The acceleration of $\left[\mathrm{Ca}^{2+}\right]_{\mathrm{i}}$ transient relaxation in reperfusion may be related to quick recovery of normal $\mathrm{K}^{+}$level, and membrane hyperpolarization, which may significantly increase the speed and efficacy of forward NCX. Furthermore the recovery of ATP level increases the 
SERCA activity as well. The reduction of $\mathrm{RT}_{50}$ below the control level during reperfusion may reflect some "overshoot" of the $\left[\mathrm{Ca}^{2+}\right]_{\mathrm{i}}$ handling during recovery [20].

Pretreatment with $10 \mu \mathrm{M}$ ORM-10103 displayed an important modulatory effect on the response of cardiomyocytes to ischemia/reperfusion. The amplitude and slope of the $\mathrm{CaT}$ were gradually decreased, although these differences became significant during the reperfusion period only. The large decrease in the amplitude of the CaT in the ORM-10103 treated group may support the notion that during ischemia the NCX mediated beat-to-beat $\mathrm{Ca}^{2+}$ influx has an important role in compensating the reduced $\mathrm{SR} \mathrm{Ca}^{2+}$ content. More importantly, the ischemia induced large increase in diastolic $\left[\mathrm{Ca}^{2+}\right]_{\mathrm{i}}$ and the elevation of $\mathrm{RT}_{50}$ were completely blocked by ORM-10103 treatment and in this case a significant decrease in these parameters could be observed during reperfusion. These results provide direct support for the hypothesis that during ischemia/reperfusion the predominant effect of ORM-10103 treatment is an effective suppression of the $\left[\mathrm{Na}^{+}\right]_{\mathrm{i}}$ accumulation induced massive activation of the reverse mode activity of NCX [50].

A further support to this conclusion was provided by the results from the strophantidine experiments. Application of $1 \mu \mathrm{M}$ strophantidine blocks the sarcolemmal $\mathrm{Na}^{+} / \mathrm{K}^{+}$-ATP-ase effectively, thus facilitating intracellular $\mathrm{Na}^{+}$accumulation, which in turn, shifts NCX activity to even more reverse direction. The ischemia induced elevation of diastolic $\left[\mathrm{Ca}^{2+}\right]_{\mathrm{i}}$ in these cells [39-40] was higher than in cardiomyocytes not treated with strophantidine, and in contrast to the untreated cells, it was further increased during reperfusion (Fig.11B). However, this effect was completely blocked by $10 \mu \mathrm{M}$ ORM10103. Another similarly important and promising effect of ORM-10103 on cellular $\left[\mathrm{Ca}^{2+}\right]_{\mathrm{i}}$ handling is summarized in (Fig.12). In strophantidine-untreated cardiomyocytes the variability of the CaT amplitude was limited and did not increase significantly during ischemia or reperfusion showing maintained control of $\mathrm{Ca}^{2+}$ release on transsarcolemmal $\mathrm{Ca}^{2+}$ fluxes. In these cells ORM-10103 had no apparent effect on variability. In contrast, CaT variability in the strophantidine-treated cells was substantially augmented during ischemia and especially during reperfusion. This is probably a consequence of the large increase in $\mathrm{Ca}^{2+}{ }_{\mathrm{i}}$ level: the steady-state balance between the trigger and feed-back system may be disturbed by the elevated $\left[\mathrm{Ca}^{2+}\right]_{\mathrm{i}}$, leading to fluctuations in the beat-to-beat $\mathrm{Ca}^{2+}$ release and instability of Ca-handling [45]. This increase was completely diminished by ORM-10103 treatment, which may be related to the reduction of $\left[\mathrm{Ca}^{2+}\right]_{\mathrm{i}}$. Since the largely increased CaT variability can be considered as a marker for the increased arrhythmia 
propensity at the cellular level [51], a reasonable interpretation of these results is that ORM-10103 is likely to decrease the incidence of $\mathrm{Ca}^{2+}$-dependent cardiac arrhythmias induced by ischemia/reperfusion.

The results of the CaT experiments seem to strongly support the beneficial effects of ORM-10103 treatment on the $\left[\mathrm{Ca}^{2+}\right]_{\mathrm{i}}$ homeostasis in cardiomyocytes during $\mathrm{I}_{\mathrm{NaL}}{ }^{-}$ mediated rise in $\left[\mathrm{Ca}^{2+}\right]_{\mathrm{i}}$ and an ischemia/reperfusion injury, by practically eliminating the $\left[\mathrm{Ca}^{2+}\right]_{\mathrm{i}}$ overload together with its detrimental consequences and by largely decreasing the arrhythmia propensity of the heart [52-53].

\subsection{Selective NCX inhibition causes only minor changes on AP morphology}

Ischemia/reperfusion induced arrhythmias are generated by two major, but not independent mechanisms: $\left[\mathrm{Ca}^{2+}\right]_{\mathrm{i}}$ overload, and depolarization of the sarcolemma [28]. $\left[\mathrm{Ca}^{2+}\right]_{\mathrm{i}}$ overload may cause increased $\mathrm{Ca}^{2+}$ leakage from the $\mathrm{SR}$, thus substantially enhancing the generation of spontaneous diastolic releases (sparks), and $\mathrm{Ca}^{2+}$-dependent triggered arrhythmias [49]. These stochastic $\mathrm{Ca}^{2+}$ releases generate large inward current, perhaps via increased forward NCX transport activity, which in turn depolarizes the sarcolemma. Therefore, these release events can serve as the trigger for potentially lethal ventricular arrhythmias [54]. Elevated $\left[\mathrm{K}^{+}\right]_{\mathrm{o}}$ causes considerable membrane depolarization reducing the availability and recovery of $\mathrm{Na}^{+}$and $\mathrm{Ca}^{2+}$ channels, furthermore the depolarization attenuates $\mathrm{Ca}^{2+}$ extrusion [48]. $\mathrm{Ca}^{2+}$ elevation may generate enhanced $\mathrm{Ca}^{2+}$ efflux through the forward NCX, meanwhile the ATP depletion induced activation of $\mathrm{I}_{\mathrm{K}(\mathrm{ATP})}$ channels carries extra repolarizing current, which may contribute to AP shortening during ischemia-reperfusion. The substantial redistribution of ion fluxes both in the repolarizing currents, and in the $\mathrm{Ca}^{2+}$ fluxes, may contribute the increased short-term $\mathrm{APD}_{90}$ variability during reperfusion. Pretreatment of normoxic (time control) cells with $10 \mu \mathrm{M}$ ORM-10103 caused a moderate shortening of the AP (Fig.13A) which may be related to the inhibition of forward NCX activity. No further apparent changes were observed. Ischemia substantially depolarized the membrane as a consequence of the enhanced $\left[\mathrm{K}^{+}\right]_{\mathrm{o}}$ (Fig.13B) and eliminated the spike potential, but both parameters were restored during reperfusion. ORM-10103 treatment failed to protect the cells against these ischemia induced changes (Fig.13C). The only beneficial effect of NCX inhibition on ischemia/reperfusion induced shifts in AP parameters was a significant reduction in APD 90 
variability during reperfusion, which may be a consequence of increased stability of $\mathrm{Ca}^{2+}$ handling following the application of ORM-10103.

The apparent failure of ORM-10103 to modulate the ischemic AP is even better shown in the panels of Fig.14. Ischemia induced changes in AP parameters (i.e. the significantly depressed amplitude (A), plateau (B), and marked triangulation (F), as well as the depolarized resting potential) were practically uninfluenced by the application of ORM-10103. As already mentioned, ischemia induced shortening of the AP (both at $\mathrm{APD}_{25}$ and $\mathrm{APD}_{90}$ levels) were even further shortened by ORM-10103 (D-E). The reason for this unability of the NCX inhibitor to prevent the protective effects of ischemia/reperfusion on the AP may be quite complex. Changes in $\left[\mathrm{Ca}^{2+}\right]_{\mathrm{i}}$ are likely important modulators of the membrane potential at any time during the cardiac cycle [49.] however, the shape and kinetics of the AP are much more dependent on several other parameters, including the inward $\mathrm{Na}^{+}$and outward $\mathrm{K}^{+}$currents. Neither of these were affected directly by ORM-10103. This may be the primary cause for the limited sensitivity of the AP to selective NCX blockade. The only apparent beneficial effect of ORM-10103 on variables of the action potential was a significant reduction in reperfusion-induced rise of $\mathrm{APD}_{90}$ variabilities [55]. This may be a consequence of the increased stability of $\mathrm{Ca}^{2+}$ handling and is most probably a consequence of the decreased $\left[\mathrm{Ca}^{2+}\right]_{\mathrm{i}}$ overload and reduced $\left[\mathrm{Ca}^{2+}\right]_{\mathrm{iD}}$. 


\section{CONCLUSION}

Until recently, the lack of proper NCX inhibitors significantly hampered the efforts to answer the question, how selective NCX inhibition would modulate the arrythmogenic consequences of severe $\mathrm{Ca}^{2+}$ overload, induced by either increased late sodium current or ischemia/reperfusion. That is the reason, why the overall conclusion of the present study, i.e. that treatment by a highly selective NCX inhibitor, ORM-10103 proved to effectively improve the cell viability during ischemia/reperfusion injury, seems to be really important.

ORM-10103 apparently normalized the stability of the $\left[\mathrm{Ca}^{2+}\right]_{\mathrm{i}}$ transient markedly weakened during reperfusion and facilitated the post-reperfusion survival of the cardiomyocytes. Its beneficial, preventive action against the arrhythmogenic shifts in $\left[\mathrm{Ca}^{2+}\right]_{\mathrm{i}}$ homeostasis caused by elevated late sodium current or ischemia/reperfusion can apparently be a consequence of its limiting effect on $\left[\mathrm{Ca}^{2+}\right]_{\mathrm{i}}$ overload and subsequent elimination of the ischemia-induced rise in diastolic $\left[\mathrm{Ca}^{2+}\right]_{i}$. These effects may have primarily contributed to the effective inhibition of the $\left[\mathrm{Na}^{+}\right]_{i}$ rise-induced, significantly enhanced reverse mode transport activity of the $\mathrm{Na}^{+} / \mathrm{Ca}^{2+}$ exchanger. On the other hand, in certain pathological conditions, where the source of arrhythmia is the disturbed AP morphology and to lesser extent the $\left[\mathrm{Ca}^{2+}\right]_{\mathrm{i}}$ overload, the protective efficacy of ORM10103 is rather limited, since it is apparent unable to prevent or significantly decrease these arrhythmogenic AP changes. Therefore, it can be stated that selective NCX inhibition might best be used to protect the heart against the arrhythmogenic effects of $\mathrm{Na}^{+}$induced $\left[\mathrm{Ca}^{2+}\right]_{\mathrm{i}}$ overload and the subsequent cell death.

Selective NCX inhibitors might be the key to find a way to have antiarrhythmic effect against the $\mathrm{I}_{\mathrm{NaL}}$-mediated and ischemia/reperfusion induced $\left[\mathrm{Ca}^{2+}\right]_{\mathrm{i}}$ overload and cell death. 


\section{LIMITATIONS}

Our studies revealed that inhibition of the NCX by applying inhibitors that does not affect the L-type $\mathrm{Ca}^{2+}$ current, the major source of $\mathrm{Ca}^{2+}$ influx, may protect the cardiac myocytes against $\left[\mathrm{Ca}^{2+}\right]_{\mathrm{i}}$ overload, preventing the deleterious consequences of the sustained high intracellular $\mathrm{Ca}^{2+}$. Since $\left[\mathrm{Ca}^{2+}\right]_{\mathrm{i}}$ overload has a crucial pathogenetic role in a variety of pathophysiological situations, our results support the hypothesis that selective NCX inhibition can be beneficial in differerent cardiac diseases. However, extrapolation of our experimental results to the human pathophysiology must be careful. For example, the severity of the simulated ischemia in our studies was only mild, thus beneficial effect of the NCX inhibition in real situations cannot be granted based solely on our results. Therefore, further studies, using more sophisticated experimental approaches, are needed to study the therapeutic potential of the NCX inhibition.

It must be emphasized, that the data provided in Fig.8 differ from data presented in Fig.s 5-15. "Survival" experiments were performed on full cell populations (the only criterion when selecting the ROI at the beginning of the experiments was to find an area with predominantly healthy, contracting cells). Our present data shown in Fig.8 and data in the literature [30] clearly demonstrate that a significant fraction of the cardiomyocytes does not survive the simulated ischemia protocol and dies during the reperfusion period. Since incomplete measurements were discarded from further proccessing, all single cell (NADH, $\mathrm{CaT}$, and AP) data presented were obtained from a limited cellular pool - i.e. surviving cells.

Furthermore, during simulated ischemia a $90 \% \mathrm{~N}_{2}-10 \% \mathrm{O}_{2}$ gas phase was directed over the top of the chamber and in the simulated ischemic solution before it arrives to the chamber. The $\mathrm{O} 2$ value was difficult to set to appropriate level in the chamber. That is the reason why this protocol characterization was really difficult. 


\section{ACKNOWLEDGEMENTS}

I am especially thankful to my supervisors András Tóth, PhD, for introducing me to the cellular fluorescent techniques and conventional microelectrode techniques, and for providing me the opportunity to work in the optical laboratory, and to Professor András Varró, MD, DSc, for his permanent support during my work at the Department of Pharmacology and Pharmacotherapy.

I am very grateful to Professor Julius Gy. Papp, MD, DSc, member of the Hungarian Academy of Sciences, for his permanent support, personal guidance, criticism, and suggestions. The helpful discussions were exceptionally useful during my work and improved my critical thinking that is needed in the scientific field.

I wish to thank my grateful colleagues, Norbert Nagy PhD, and Károly Acsai PhD, for their continuous support during my work in the field of the electrophysiology.

I would like to thank all my direct colleagues, Judit Szepesi MSc, Nikolett Nagy MSc, and to János Prorok PhD for their help in my work. I am also very thankful to Ms. Andrea Gruber MSc for her helpful technical assistance.

Finally, I wish to thank, and dedicate this thesis to my whole family and to my friends for their love, help and encouragement. Last but not least, my deepest appreciation goes to my husband, for his love, support and encouragement.

The publication is supported by the Richter Gedeon Talentum Foundation and by grants from the Hungarian Scientific Research Fund (NK-104331), the National Office for Research and Technology-Baross Programmes (REG-DA-09-2-2009-0115-NCXINHIB), the National Development Agency and co-financed by the European Regional Fund (TÁMOP-4.2.2A-11/1/KONV-2012-0073 and TÁMOP-4.2.2.A-11/1/KONV-2012-0060 ), the HU-RO Cross-Border Cooperation Programmes (HURO/1001/086/2.2.1_HUROTWIN) and the Hungarian Academy of Sciences. 


\section{REFERENCES}

[1.] Bourdillon, P.D., Poole-Wilson, P.A., 1981. Effects of ischaemia and reperfusion on calcium exchange and mechanical function in isolated rabbit myocardium. Cardiovasc Res $15,121-130$.

[2.] Diaz, M.E., O'Neill, S.C., Eisner, D.A., 2004. Sarcoplasmic reticulum calcium content fluctuation is the key to cardiac alternans. Circ Res 94, 650-656.

[3.] Diaz, M.E., Trafford, A.W., O'Neill, S.C., Eisner, D.A., 1997. Measurement of sarcoplasmic reticulum $\mathrm{Ca} 2+$ content and sarcolemmal $\mathrm{Ca} 2+$ fluxes in isolated rat ventricular myocytes during spontaneous Ca2+ release. J Physiol 501 ( Pt 1), 3-16.

[4.] Bers, D.M., 2008. Calcium cycling and signaling in cardiac myocytes. Annu Rev Physiol 70, 23-49.

[5.] Bers, DM, Despa, S, Bossuyt, J: Regulation of $\mathrm{Ca} 2+$ and $\mathrm{Na}+$ in normal and failing cardiac myocytes. Ann N Y Acad Sci. 2006; 1080: 165-177.

[6.] Wu L, Ma J, Li H, Wang C, Grandi E, Zhang P, et al. Late sodium current contributes to the reverse rate-dependent effect of $\mathrm{IKr}$ inhibition on ventricular repolarization. Circulation. Apr 26;123(16):1713-20.

[7.] Kiyosue T, Arita M. Late sodium current and its contribution to action potential configuration in guinea pig ventricular myocytes. Circ Res. 1989 Feb;64(2):389-97.

[8.] Horvath B, Banyasz T, Jian Z, Hegyi B, Kistamas K, Nanasi PP, et al. Dynamics of the late $\mathrm{Na}(+)$ current during cardiac action potential and its contribution to afterdepolarizations. J Mol Cell Cardiol. Nov;64:59-68.

[9.] Bers DM, Weber CR. Na/Ca exchange function in intact ventricular myocytes. Ann N Y Acad Sci. 2002 Nov;976:500-12.

[10.] Schulze DH, Muqhal M, Lederer WJ, Ruknudin AM. Sodium/calcium exchanger (NCX1) macromolecular complex. J Biol Chem. 2003 Aug 1;278(31):28849-55.

[11.] Nicoll, D.A.; Sawaya, M.R.; Kwon, S.; Cascio, D.; Philipson, K.D.; Abramson, J. The crystal structure of the primary $\mathrm{Ca} 2+$ sensor of the $\mathrm{Na}+\mathrm{Ca} 2+$ exchanger reveals a novel Ca2+ binding motif. J. Biol. Chem., 2006, 281, 21577-21581.

[12.] Lytton, J. $\mathrm{Na}+\mathrm{Ca} 2+$ exchangers: three mammalian gene families control $\mathrm{Ca} 2+$ transport. Biochem. J., 2007, 406, 365-382.

[13.] Rocchetti M, Besana A, Gurrola GB, Possani LD, Zaza A (2001). Ratedependency of delayed rectifier currents during the guinea-pig ventricular action potential. $J$ Physio., 534: 721-732.

[14.] Lopatin AN, Makhina EN, Nichols CG (1994). Potassium channel block by cytoplasmic poly amines as the mechanism of intrinsic rectification. Nature, 372: 366-369. [15.] Ishihara K, Mitsuiye $\mathrm{T}$, Noma $\mathrm{A}$, Takano $\mathrm{M}$ (1989). The $\mathrm{Mg}^{2+}$ block and intrinsic gating underlying inward rectification of the $\mathrm{K}^{+}$current in guinea-pig cardiac myocytes. $J$ Physiol., 419: 297-320.

[16.] Smith PL, Baukrowitz T, Yellen G (1996). The inward rectification mechanism of the HERG cardiac potassium channel. Nature, 37, 833-836.

[17.] Shimoni Y, Clark RB, Giles WR (1992). Role of inwardly rectifying potassium current in rabbit ventricular action potential. J Physiol., 448: 709-727. 
[18.] Ravens U, Cerbai E. Role of potassium currents in cardiac arrhythmias. Europace. 2008 Oct; 10(10): 1133-7.

[19.] Anderson, S., 2002. Response to: Effect of inhibition of Na+/Ca+ exchanger at the time of myocardial reperfusion on hypercontracture and cell death. Cardiovascular Research 55, 706-707.

[20.] Talukder, M.A., Zweier, J.L., Periasamy, M., 2009. Targeting calcium transport in ischaemic heart disease. Cardiovasc Res 84, 345-352.

[21.] Allen, D.G., Orchard, C.H., 1987. Myocardial contractile function during ischemia and hypoxia. Circ Res 60, 153-168.

[22.] Lu, J., Zang, W.J., Yu, X.J., Chen, L.N., Zhang, C.H., Jia, B., 2005. Effects of ischaemia-mimetic factors on isolated rat ventricular myocytes. Exp Physiol 90, 497-505.

[23.] Bourdillon, P.D., Poole-Wilson, P.A., 1981. Effects of ischaemia and reperfusion on calcium exchange and mechanical function in isolated rabbit myocardium. Cardiovasc Res $15,121-130$.

[24.] Xie JX, Li X, Xie Z. Regulation of renal function and structure by the signaling Na/K-ATPase. IUBMB Life. Dec;65(12):991-8.

[25.] Zucchi, R., Ronca-Testoni, S., 1997. The sarcoplasmic reticulum Ca2+ channel/ryanodine receptor: modulation by endogenous effectors, drugs and disease states. Pharmacol Rev 49, 1-51.

[26.] Zucchi, R, Ghelardoni, S, Evangelista, S: Biochemical basis of ischemic heart injury and of cardioprotective interventions. Curr Med Chem. 2007; 14: 1619-1637.

[27.] Farkas AS, Acsai K, Nagy N, Toth A, Fulop F, Seprenyi G, et al. $\mathrm{Na}(+) / \mathrm{Ca}(2+)$ exchanger inhibition exerts a positive inotropic effect in the rat heart, but fails to influence the contractility of the rabbit heart. Br J Pharmacol. 2008 May; 154(1): 93-104.

[28.] MacDonald, A.C., Howlett, S.E., 2008. Differential effects of the sodium calcium exchange inhibitor, KB-R7943, on ischemia and reperfusion injury in isolated guinea pig ventricular myocytes. Eur J Pharmacol 580, 214-223.

[29.] Maddaford, T.G., Hurtado, C., Sobrattee, S., Czubryt, M.P., Pierce, G.N., 1999. A model of low-flow ischemia and reperfusion in single, beating adult cardiomyocytes. Am J Physiol 277, H788-798.

[30.] Moens, A.L., Claeys, M.J., Timmermans, J.P., Vrints, C.J., 2005. Myocardial ischemia/reperfusion-injury, a clinical view on a complex pathophysiological process. Int $\mathbf{J}$ Cardiol 100, 179-190.

[31.] Nguyen TP, Wang DW, Rhodes TH, George AL, Jr. Divergent biophysical defects caused by mutant sodium channels in dilated cardiomyopathy with arrhythmia. Circ Res. 2008 Feb 15;102(3):364-71

[32.] Fuller W, Tulloch LB, Shattock MJ, Calaghan SC, Howie J, Wypijewski KJ. Regulation of the cardiac sodium pump. Cell Mol Life Sci. Apr;70(8):1357-80.

[33.] Shryock, JC, Song, Y, Rajamani, S, Antzelevitch, C, Belardinelli, L The arrhythmogenic consequences of increasing late INa in the cardiomyocyte. Cardiovasc Res 99(4): 600-611.

[34.] Jost, N., Nagy, N., Corici, C., Kohajda, Z., Horvath, A., Acsai, K., Biliczki, P., Levijoki, J., Pollesello, P., Koskelainen, T., Otsomaa, L., Toth, A., Papp, J.G., Varro, A., Virag, L., ORM-10103, a novel specific inhibitor of the $\mathrm{Na}+\mathrm{Ca} 2+$ exchanger, decreases 
early and delayed afterdepolarizations in the canine heart. British Journal of Pharmacology 2013. 170, 768-778.

[35.] Louch, W.E., Ferrier, G.R., Howlett, S.E., 2002. Changes in excitation-contraction coupling in an isolated ventricular myocyte model of cardiac stunning. Am J Physiol Heart Circ Physiol 283, H800-810.

[36.] Allen, D.G., Orchard, C.H., 1987. Myocardial contractile function during ischemia and hypoxia. Circ Res 60, 153-168.

[37.] Diaz, R.J., Wilson, G.J., 2006. Studying ischemic preconditioning in isolated cardiomyocyte models. Cardiovasc Res 70, 286-296.

[38.] Frohlich, G.M., Meier, P., White, S.K., Yellon, D.M., Hausenloy, D.J., Myocardial reperfusion injury: looking beyond primary PCI. Eur Heart J 2013 34, 1714-1722.

[39.] Inserte, J., Garcia-Dorado, D., Ruiz-Meana, M., Padilla, F., Barrabes, J.A., Pina, P., Agullo, L., Piper, H.M., Soler-Soler, J., 2002. Effect of inhibition of $\mathrm{Na}(+) / \mathrm{Ca}(2+)$ exchanger at the time of myocardial reperfusion on hypercontracture and cell death. Cardiovasc Res 55, 739-748.

[40.] O'Brien, J.D., Ferguson, J.H., Howlett, S.E., 2008. Effects of ischemia and reperfusion on isolated ventricular myocytes from young adult and aged Fischer 344 rat hearts. Am J Physiol Heart Circ Physiol 294, H2174-2183.

[41.] Acsai, K., Kun, A., Farkas, A.S., Fulop, F., Nagy, N., Balazs, M., Szentandrassy, N., Nanasi, P.P., Papp, J.G., Varro, A., Toth, A., 2007. Effect of partial blockade of the $\mathrm{Na}(+) / \mathrm{Ca}(2+)$-exchanger on $\mathrm{Ca}(2+)$ handling in isolated rat ventricular myocytes. Eur $\mathrm{J}$ Pharmacol 576, 1-6.

[42.] Birinyi, P., Acsai, K., Banyasz, T., Toth, A., Horvath, B., Virag, L., Szentandrassy, N., Magyar, J., Varro, A., Fulop, F., Nanasi, P.P., 2005. Effects of SEA0400 and KB$\mathrm{R} 7943$ on $\mathrm{Na}+/ \mathrm{Ca} 2+$ exchange current and L-type $\mathrm{Ca} 2+$ current in canine ventricular cardiomyocytes. Naunyn Schmiedebergs Arch Pharmacol 372, 63-70.

[43.] Tanaka H, Namekata I, Takeda K, Kazama A, Shimizu Y, Moriwaki R et al. Unique excitation-contraction characteristics of mouse myocardium as revealed by SEA0400, a specific inhibitor of Na+-Ca2+ exchanger. Naunyn Sch. Arch Pharmacol; 371: 526-534 2005.

[44.] Bers DM. Excitation-contraction coupling and cardiac contractile force. Kluwer Academic Publishers, Dordrecht 2001.

[45.] Eisner, D.A., Diaz, M.E., Li, Y., O'Neill, S.C., Trafford, A.W., 2005. Stability and instability of regulation of intracellular calcium. Exp Physiol 90, 3-12.

[46.] Eng, J., Lynch, R.M., Balaban, R.S., 1989. Nicotinamide adenine dinucleotide fluorescence spectroscopy and imaging of isolated cardiac myocytes. Biophys J 55, 621630 .

[47.] Bountra, C.; Vaughan-Jones, R.D. Effect of intracellular and extracellular pH on contraction in isolated, mammalian cardiac muscle. J. Physiol., 1989, 418, 163-187.

[48.] Lukas, A., Antzelevitch, C., 1993. Differences in the electrophysiological response of canine ventricular epicardium and endocardium to ischemia. Role of the transient outward current. Circulation 88, 2903-2915.

[49.] Lee, J.A., Allen, D.G., 1992. Changes in intracellular free calcium concentration during long exposures to simulated ischemia in isolated mammalian ventricular muscle. Circ Res 71, 58-69. 
[50.] Wei, G.Z., Zhou, J.J., Wang, B., Wu, F., Bi, H., Wang, Y.M., Yi, D.H., Yu, S.Q., Pei, J.M., 2007. Diastolic $\mathrm{Ca} 2+$ overload caused by $\mathrm{Na}+\mathrm{Ca} 2+$ exchanger during the first minutes of reperfusion results in continued myocardial stunning. Eur J Pharmacol 572, 111.

[51.] Tokuno, T., Muraki, K., Watanabe, M., Imaizumi, Y., 2000. Protective effect of benidipine against the abnormal electrical activity in single ventricular myocytes of the guinea pig under simulated ischemic conditions and reperfusion. Jpn J Pharmacol 82, 199209.

[52.] Sipido KR, Bito V, Antoons G, Volders PG, Vos MA. Na/Ca exchange and cardiac ventricular arrhythmias. Ann N Y Acad Sci. 2007 Mar;1099:339-48.

[53.] Nattel S, Maguy A, Le Bouter S, Yeh YH. Arrhythmogenic ion-channel remodeling in the heart: heart failure, myocardial infarction, and atrial fibrillation. Physiol Rev. 2007 Apr;87(2):425-56.

[54.] Nagy, Z.A., Virag, L., Toth, A., Biliczki, P., Acsai, K., Banyasz, T., Nanasi, P., Papp, J.G., Varro, A., 2004. Selective inhibition of sodium-calcium exchanger by SEA-0400 decreases early and delayed after depolarization in canine heart. Br J Pharmacol 143, 827831.

[55.] Baczko, I., Giles, W.R., Light, P.E., 2003. Resting membrane potential regulates $\mathrm{Na}(+)-\mathrm{Ca} 2+$ exchange-mediated $\mathrm{Ca} 2+$ overload during hypoxia-reoxygenation in rat ventricular myocytes. J Physiol 550, 889-898. 


\section{ANNEX}

Publications related to the subject of the Thesis. 